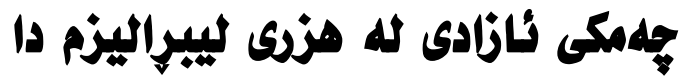

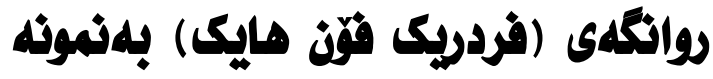

\section{جبار اسماعيل احمد}

بهشى زانسته راميارييهكان، كوليزّى زانسته راميارييهكان، زانكوى سليمانى، سليّمانى، هـريّمى كوردستان، عيّراق. ئيمهيلّ: jabar.ahmed84@gmail.com

هوخته:

لييراليزم بهوجوره له جهمكى نـازادى دهروانيتت كه بونيـاديكى ســـرهكى بنهمـا هزرييهكهيهتى و بهبى

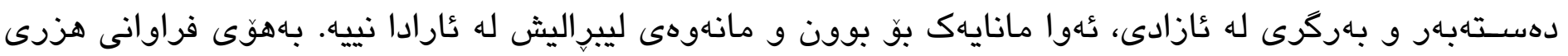

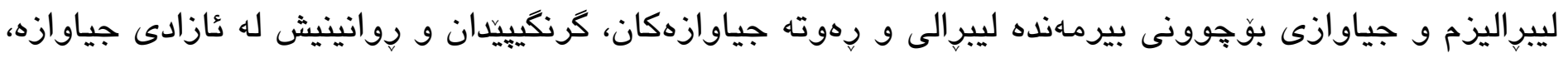

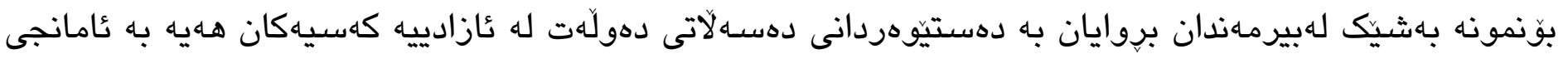

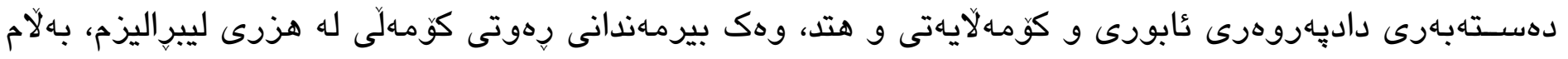

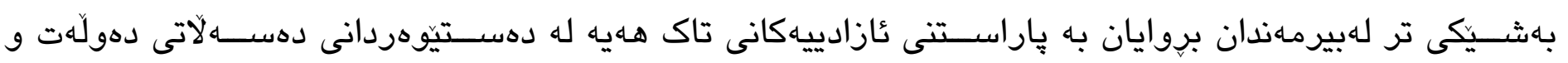

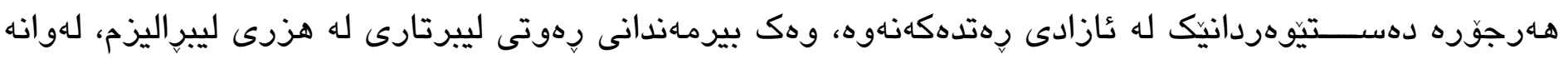

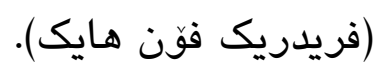

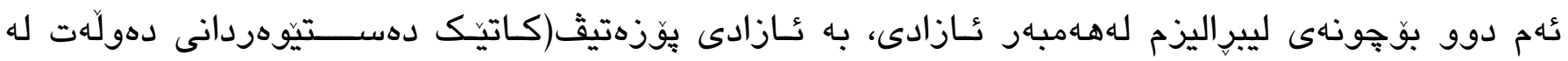

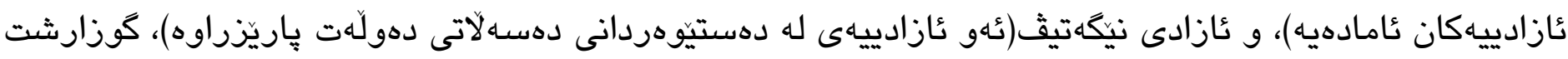

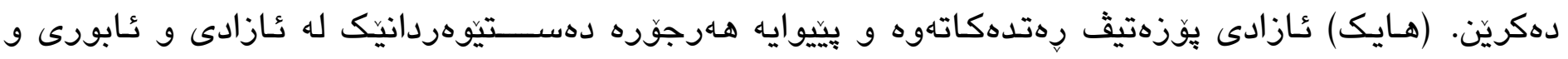

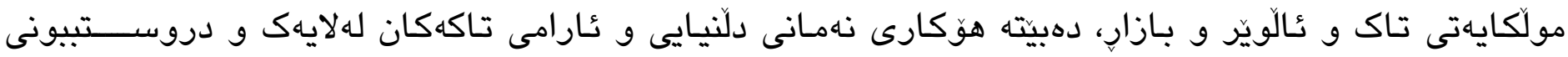

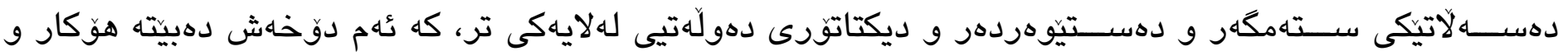

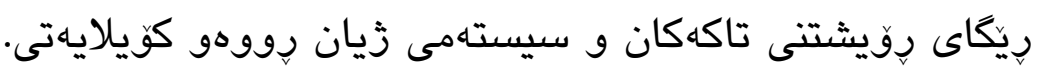
كايله ووشأكان: عازادى، هايك، ليبراليزم، ليبرتاريزم. 


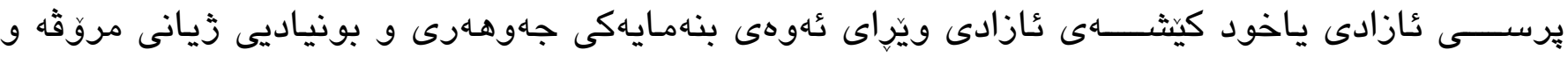
كاريكَرى تهواوى لهســهر مانا و دهلالهتهانى بوونى مروق و بهختهوهرى و تواناكانى داهينان و دهســتهبهرى

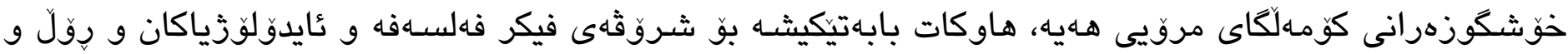
ئهركى دهولّت و ســنورى كارهكانى و بهايوهندييهكانى به زيانى تايبهتى تاكهكان و هاوكات بهيوهندييهكانى بازار

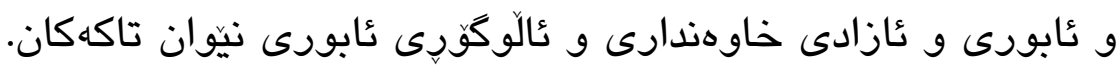

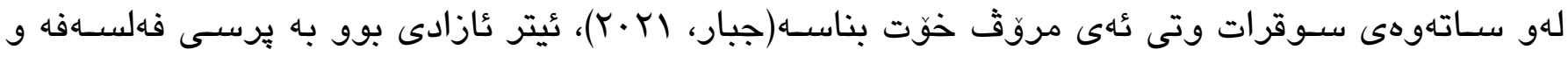

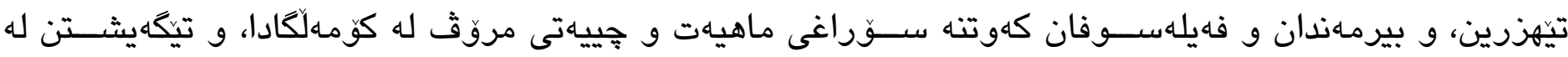

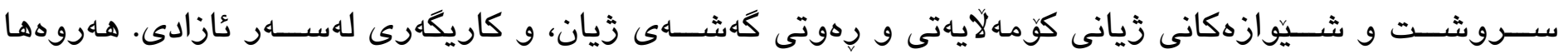

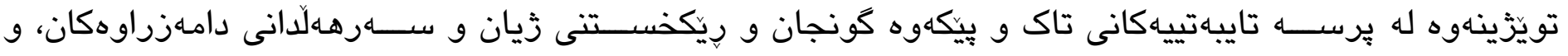

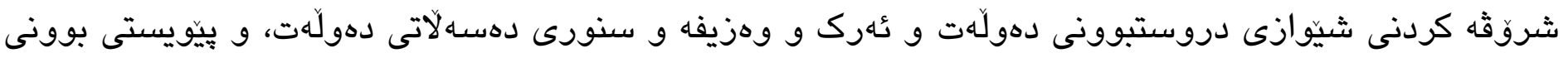

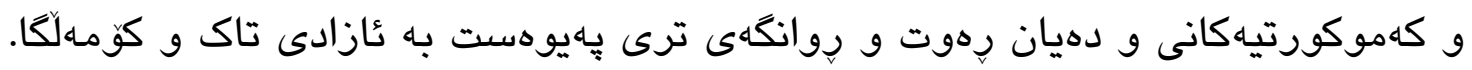

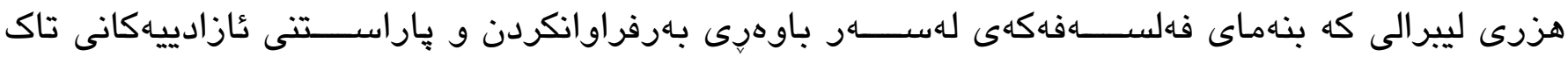

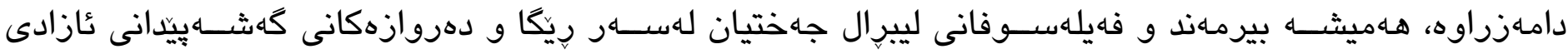

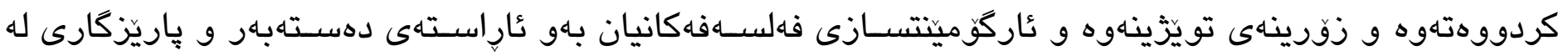

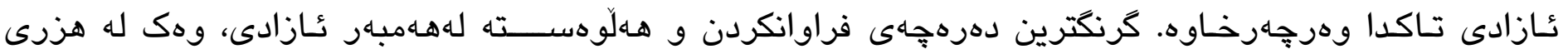

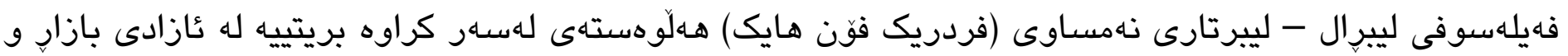

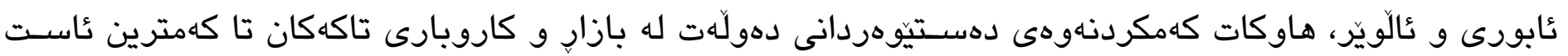
و ماهوداى له توانادابوو.

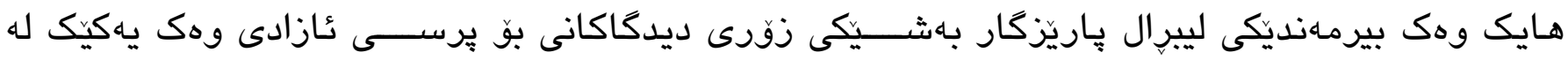

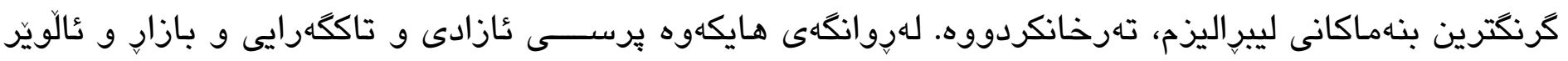

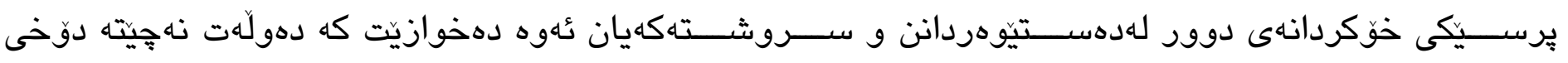

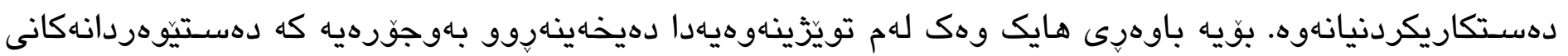

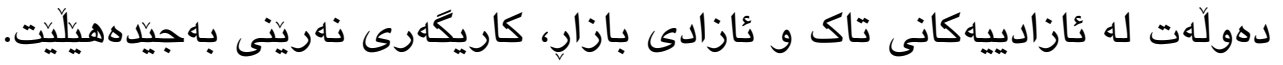




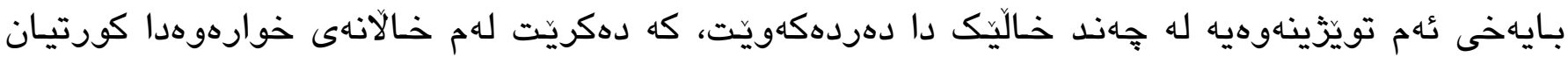
بكهينهوه:

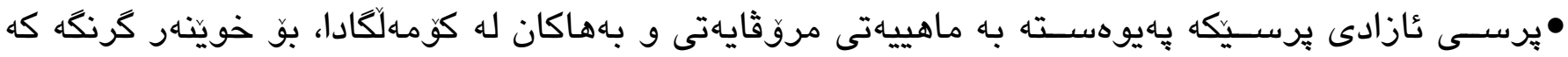
رِههانده جوّرييهكانى ئهو بِرسه شارهزايتيت و روئياجياوازهكان لههـمبهر عازاده يناسيّت.

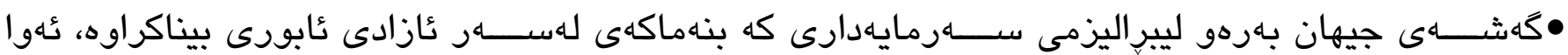

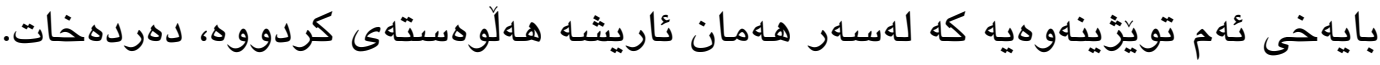
•رِوت و هزره هـاوجاءرخهكانى ليبراليزم و بوّجونهانيان دهربارهى ئازادى و كاريكاهرييان له دونياىى

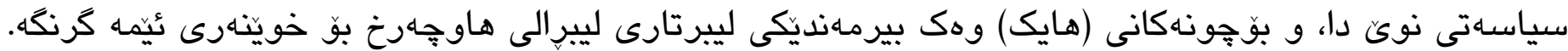
•كهمى نوســين و تويّزينهوهى ئاكاديمى كوردى زمان دهربارهى هزرى ليبرتاريانيزم و ديدكاكانى (هايك) لايهنيكى ترى بايهخ و كرنكى ئهم تويزّينهوهيه دهردهخات.

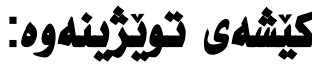

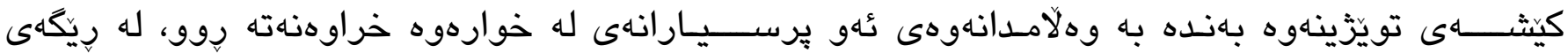

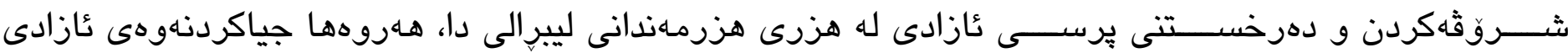

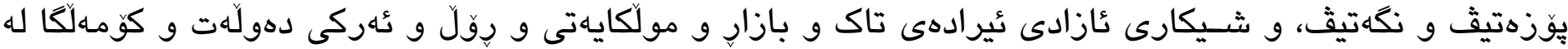

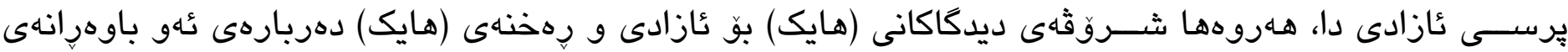
دهمانبهن بارهو كويلايهتى، كرنكترين برسيارهكانيش بريتين له:

•روانكه هزرييهكان تاجهند توانيويانه بنهماكانى ئازادى وهك دهرفهتى مامهلّهيانهى زيان بو تاك دهستهبهر بكهن

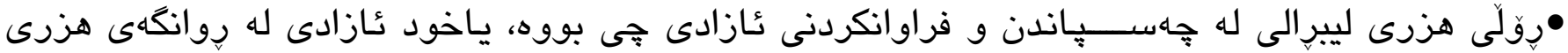
لييراليهوه جى دهلالهت و ماهيهتيك به خود و رِهتارى تاك دهبهخشيت؟

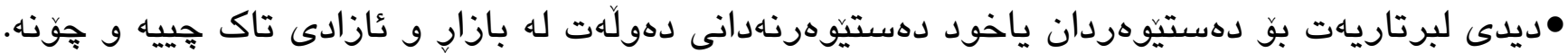

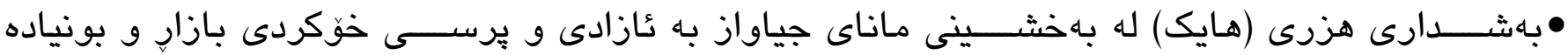

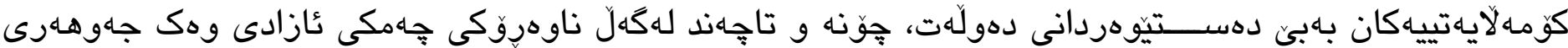
بهخشينى خوّشبهختى به مروّايهتى هاوتا و كونجاوه؟ 


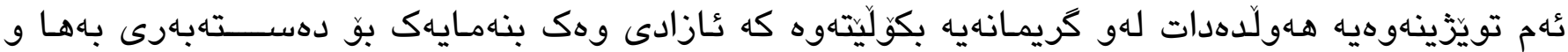
بهختهوهرى مروّيى بيّويسـته لهدهرهوهى دهســلات و دهسـتيّوهردانى دهولّت بيّت، هـروهها ديدكا هزرييهكانى

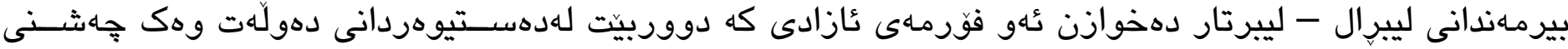

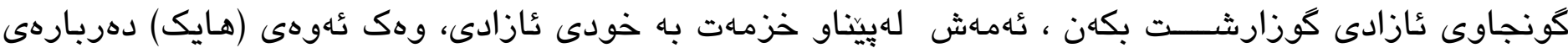

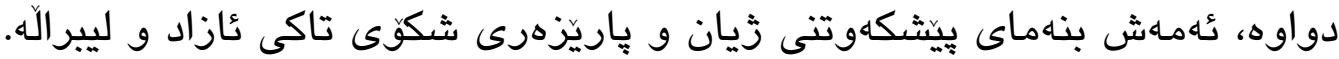

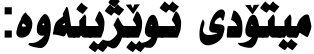

لهم تويزّينهوهيهدا و لهيِيناو شيكردنهوهى ووردى جهامكى ئازادى، ميتودى (شيكردنهوهى دهق)مان به بنهما

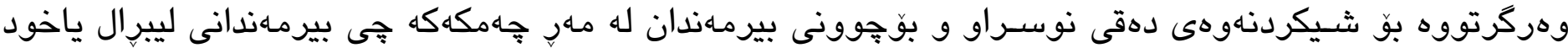

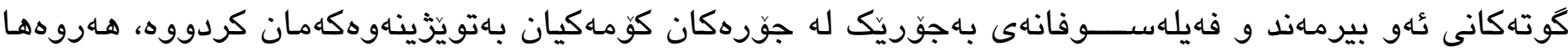

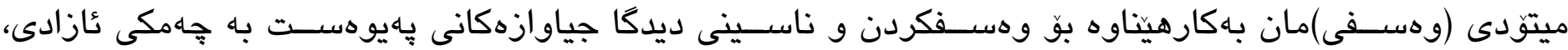

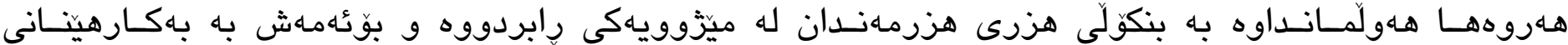
عامرازهكان عاركيولؤزياى هزرى كارهكهمان به ئاكام كهياندووه، جونكه هـه هزريكّ لهكات و شـوينيكى دياريكراو

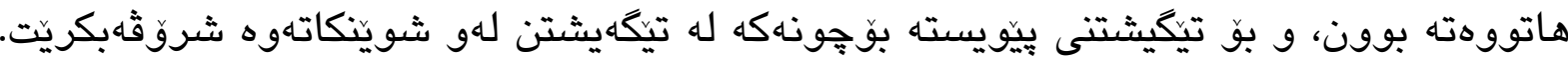

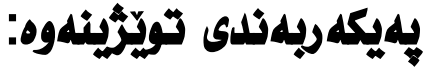

ئهم تويَزينهوهيه بينكديت له يِيثـسكى و دوو باس و دهرئهنجام، باسسى يهكهم تايبهته به جوارجيوهى كَثـتى

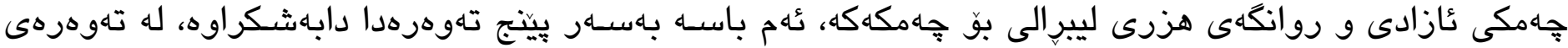

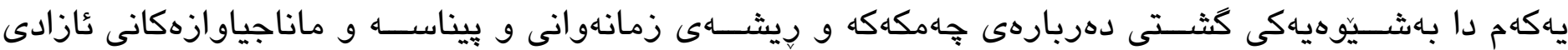
دواوين، له تهوهرهى دووهم دا هزرى هزرمهندانى ليبراليمان له ربابردووى عٔهو رهوتهدا خسـتووهته روو كه تيايدا

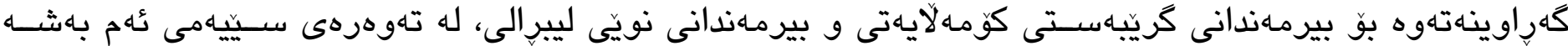

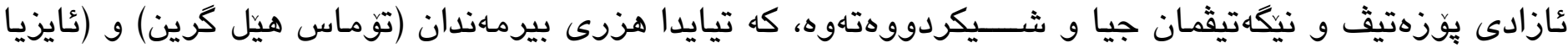
بهرلين) بو ئه جياكارييه وهركيراوه، بهو يِييهى دوو هزرمهندى لييرالين و له نوســـينهانيان دا جهختيان لهم دابهشكارييه كردووهتهوه و سهر به دوو سهردهمى ميّزوويى جياوازى ليبراليزمن، له جوارهم تهوهرهش دا لهسهر عازادى تاك وهسـتاوين و بنهماى تاكگَهايى ليبراليمان شـيكردووهتهوه، كؤتا تهوهرهش تهرخانه بو ئيرادهى ئازاد 
و روانكهى بيرمهندانى مـسـيحى دهربارهى رِتكردنهوهى ئيرادهى ئازادمان خســووهته روو وهكو لايهنى دز و ناهيار.

باسى دووهمى تويَّزينهوهكه تايبهته به خستنهرووى هزرى (هايك) دهربارهى جֶهمكى ئازادى، لهم باسهادا و

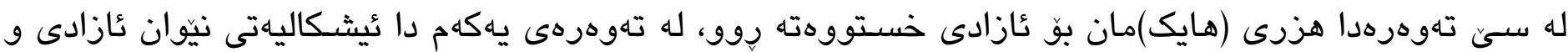

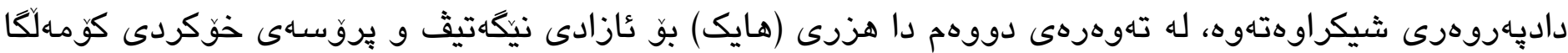

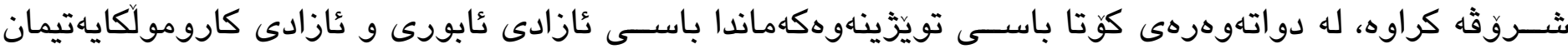
كردووه كه (هايك) وهكو بنهمايهكى سهردكى و كرنكى ليبراليزم دهيبينيت.

\section{باسى يلمكلم}

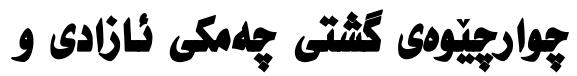

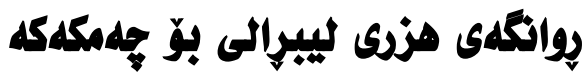

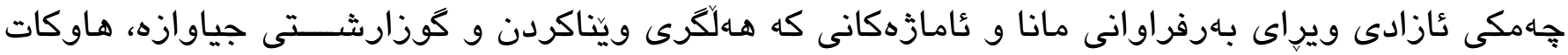

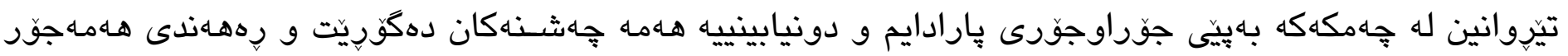
وهردهكريت و دهلالهتى جياواز لهخودهكريّت.

روانكاىى ليبراليزم بههوى فرهيى له بوجوونى بيرماندانيدا و فراوانبوونى عايديا ليبرالييهكان و دابهشبوونيان

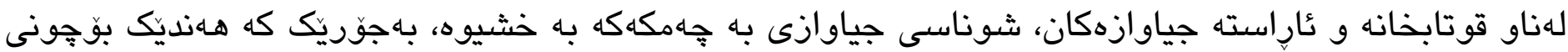

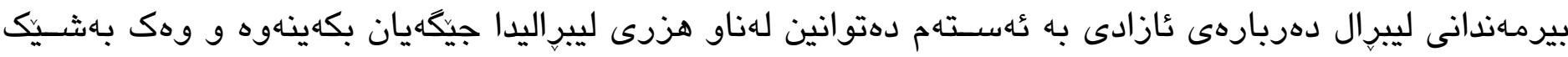

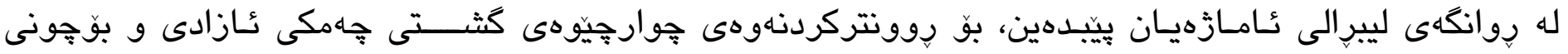

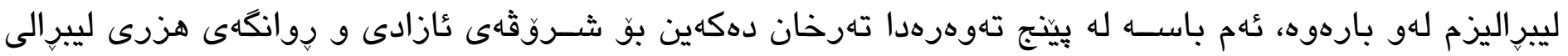
بوّ ئازادى.

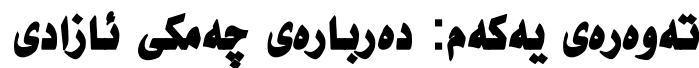

ويسـتى فهلسـهافه له جيهانى هاوجهرخ دا بريتييه له جارهسـهـى كثــكانى مروّق و كَهاندنى به كهنارى

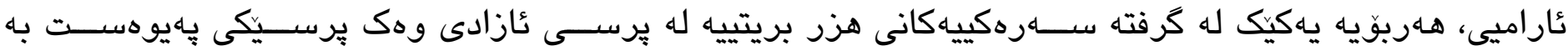

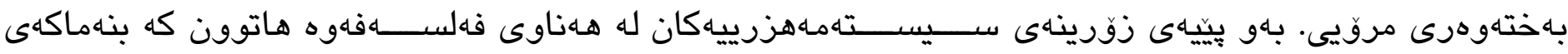

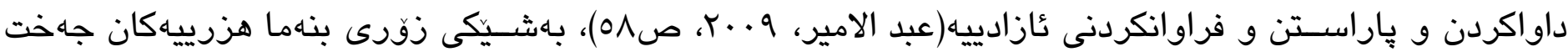




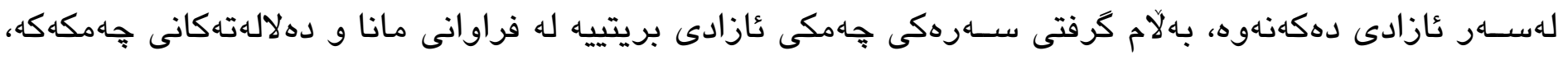

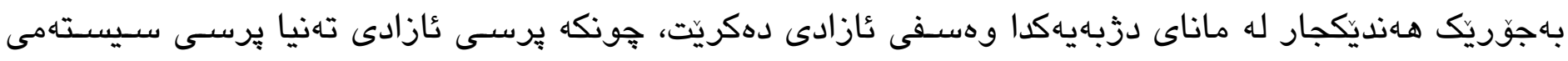

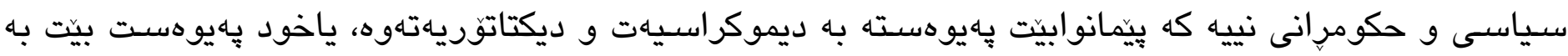

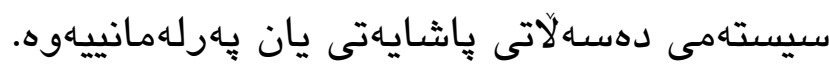

هـروهها تهنيا ياســا تايبهتهكانى بهندكردن و عازادكردن نييه، و كورتيش نابيتهوه تهنيا له عئهكامى عورفى

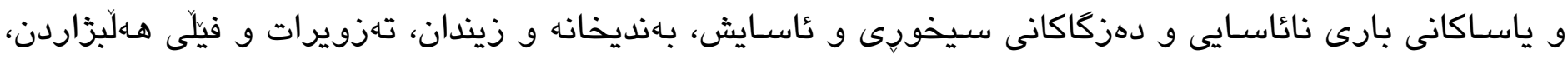

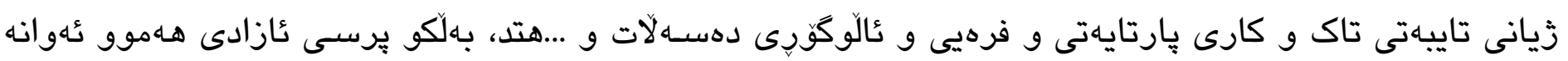

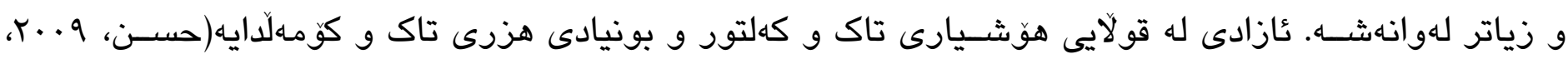
ص ص (IV7)

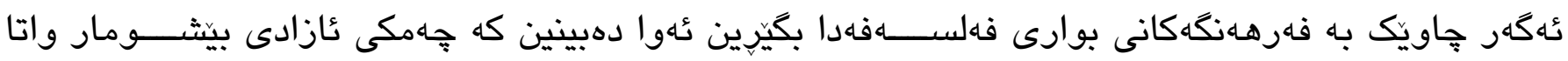

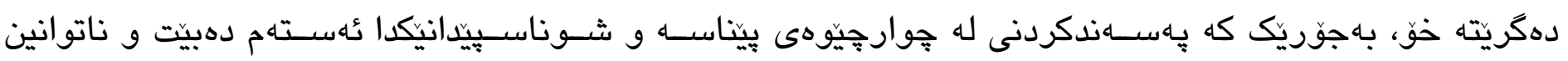

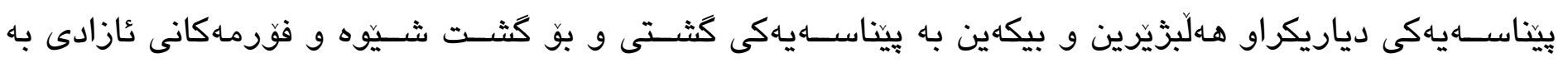

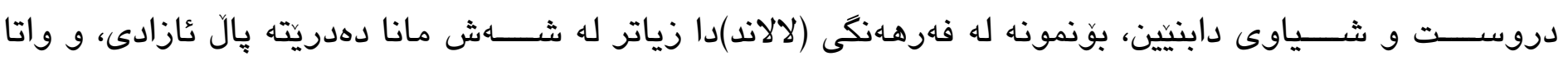

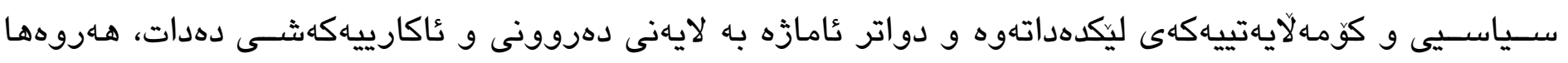

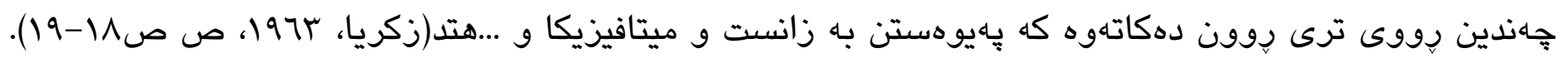
ئازادى ئهكهر وهك ووشـه وهرييكرين ئهوا بنهماكهى له زمانى فهرهنسيدا ووشسهى (iberte)يه، و له زمانى

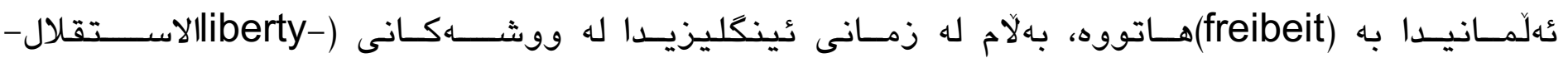

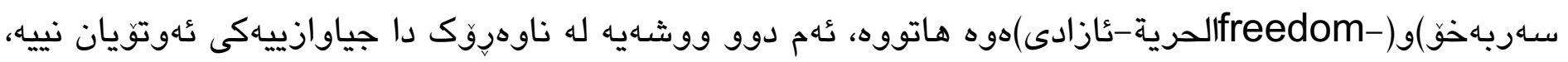

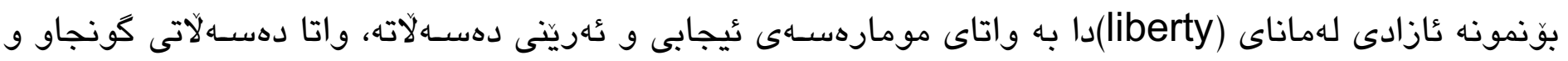

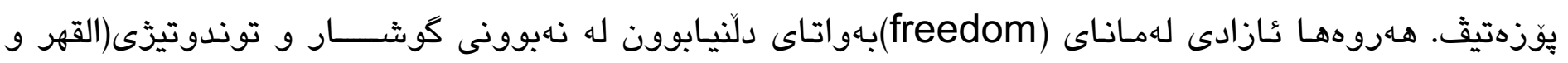

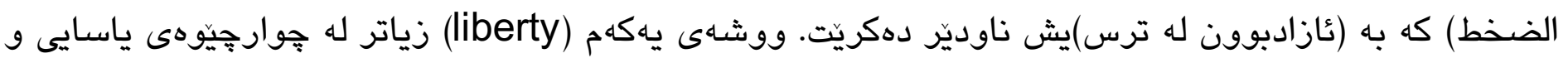

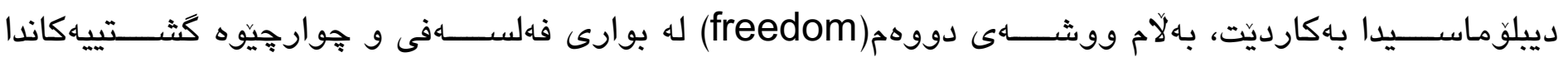

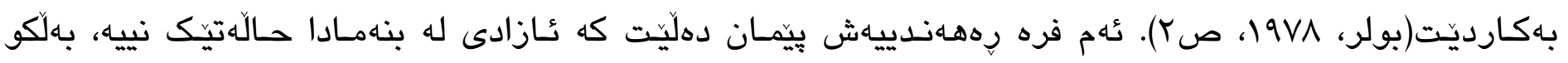

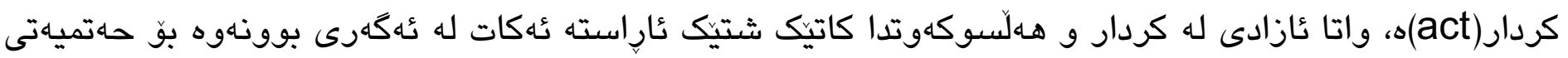

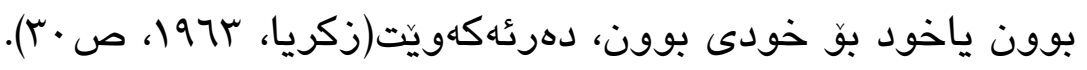




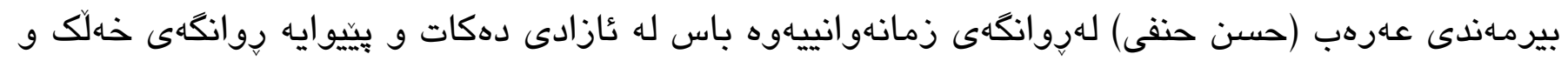

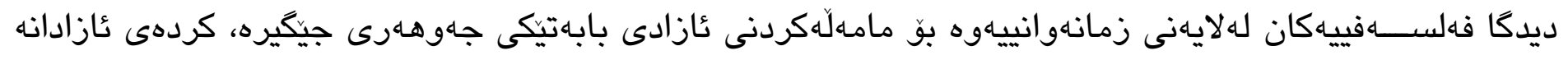

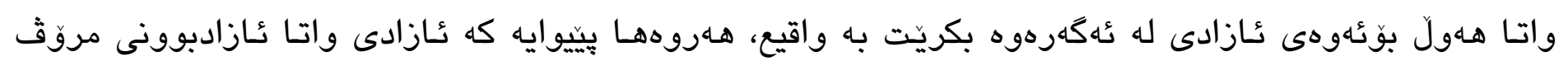

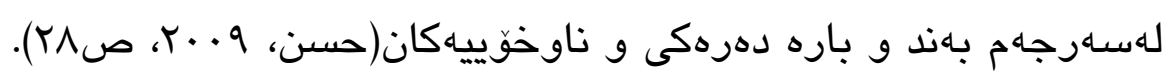

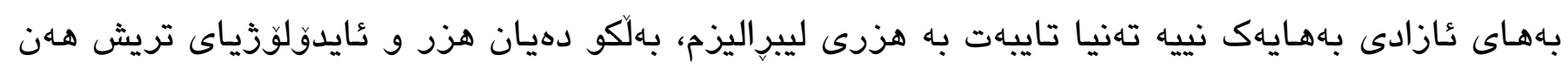
كه له تيوّرهكانيان دا يشـت بـه عُازادى دهبهستن، بهلاّم ئهوهى عازادى ليبراليزم له رِوانكه جياوازهكانى ترى ئازادى

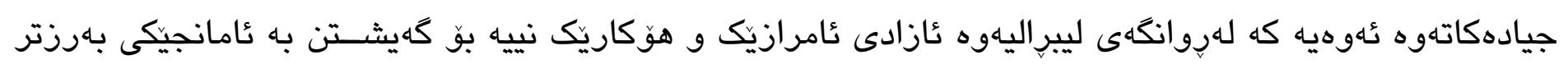

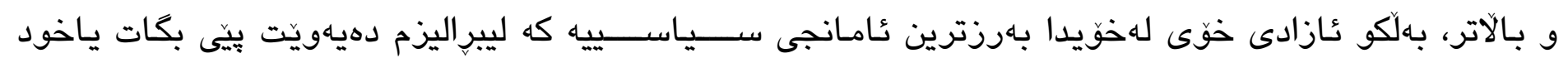

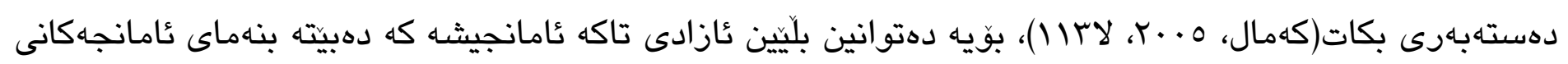

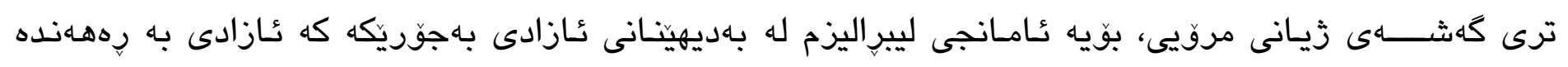

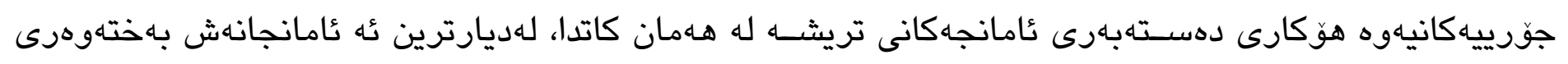
و داديهروهرى و كهشهى ثيان و نابورييه.

\section{تلهوهرهى دووم: ثازادى لله هزرى ليبيراليزم دا}

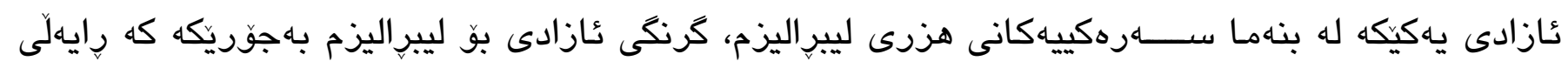
ســهرهكى فهلســهذكهى ديارى دهكات و بـهيَ تازادى بوونى ليبراليزميش ماناى خوّى لهدهسـت دهدات. ليبراليزم

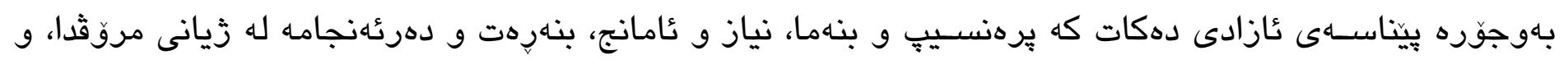

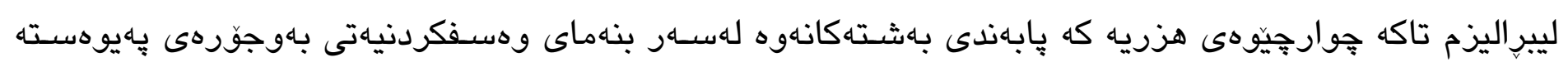

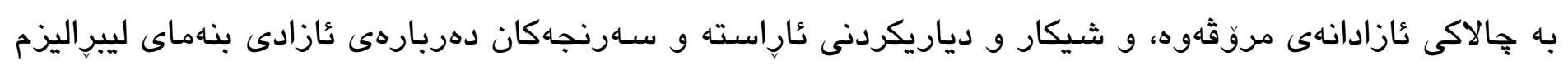

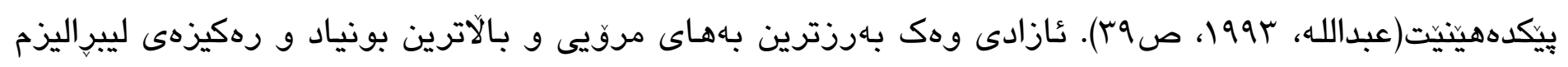

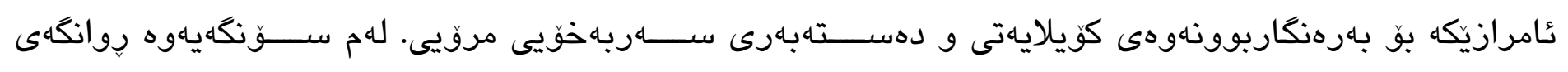

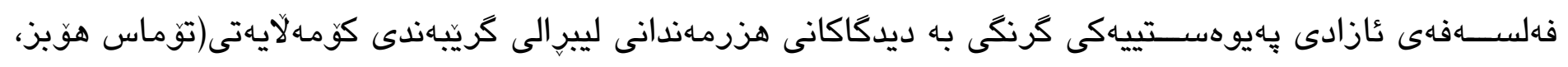

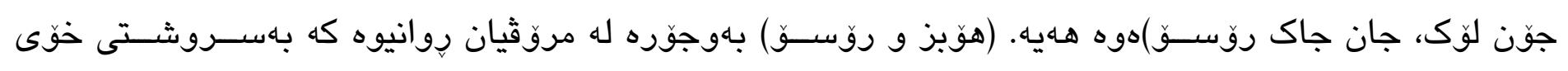

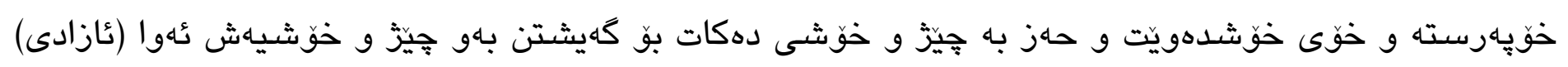
دهرفهت للهبهردهم مروقهكاندا دهكاتهوه و هاوكار دهبيت بو كُيشـتن به تيّركردنى تُارهووهكان و بهدهسـتهينانى

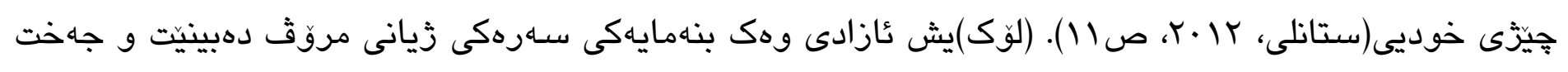

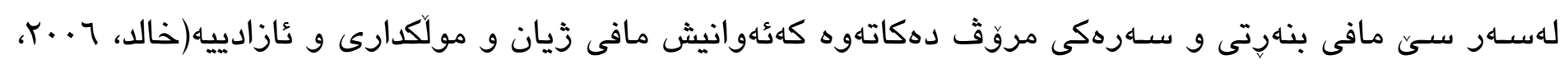

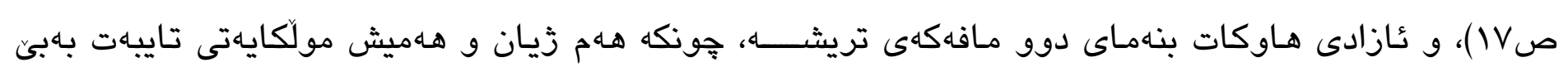




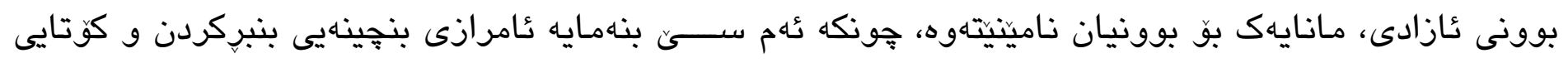
يّيّهينانى كويلايهتين.

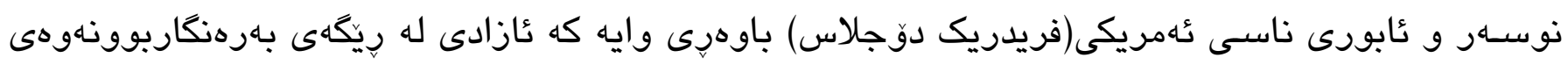

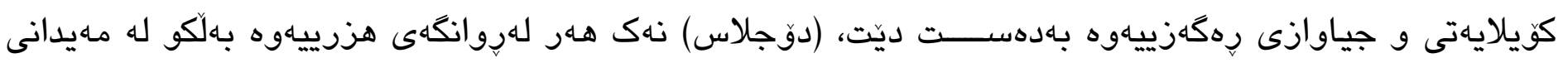

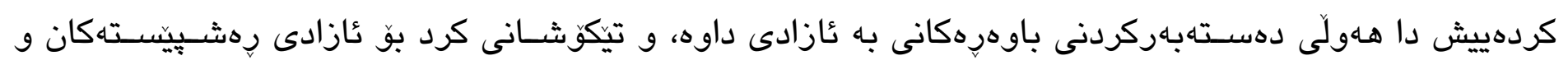

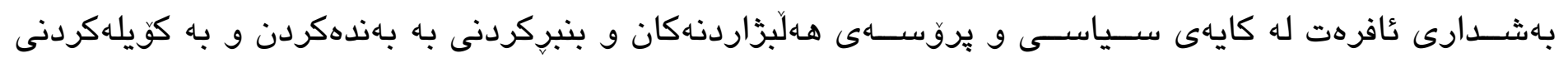

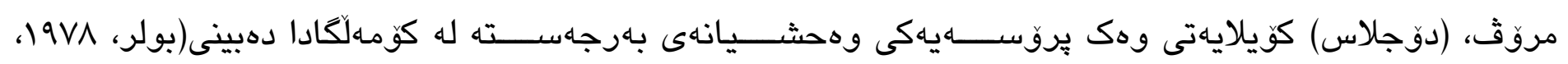

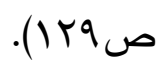

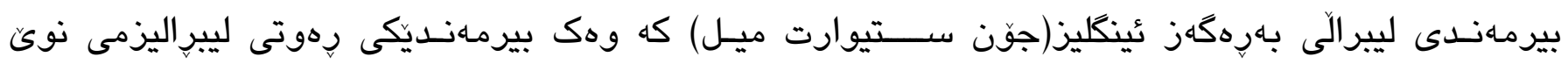

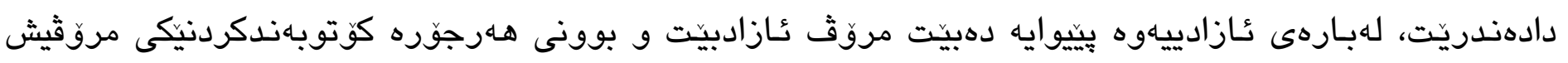

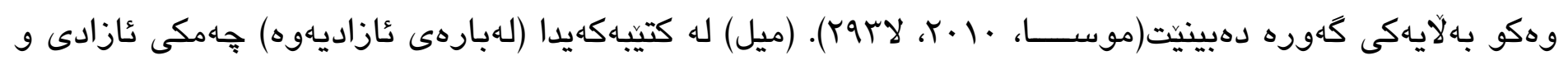

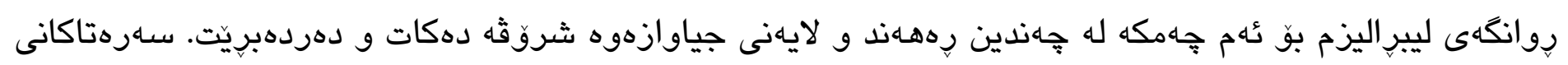

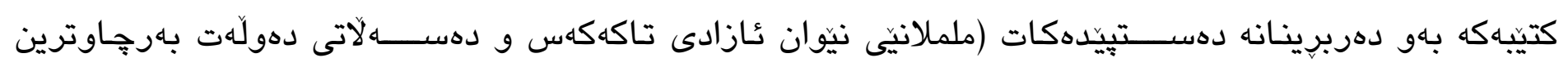

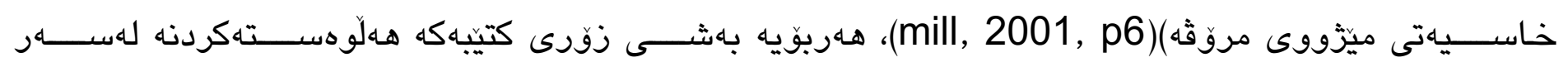

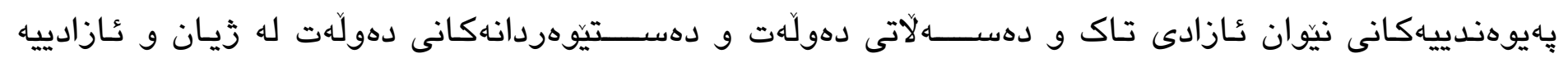

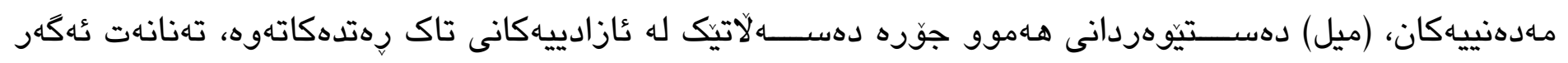

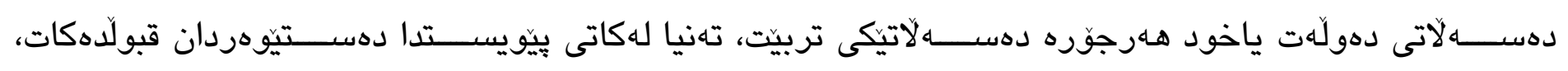

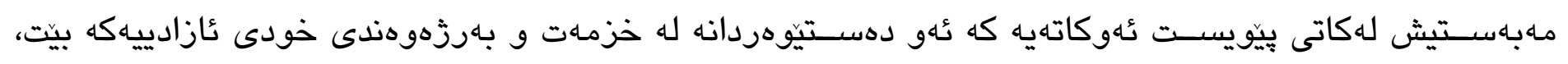

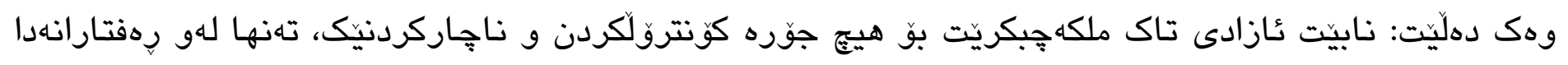

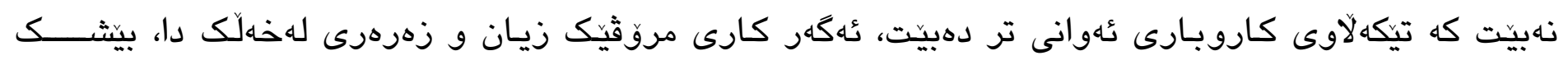

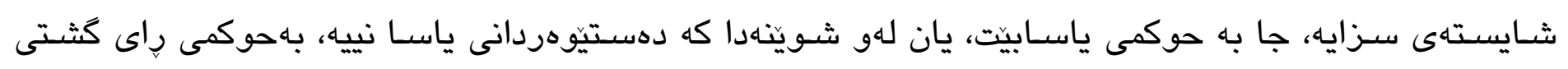

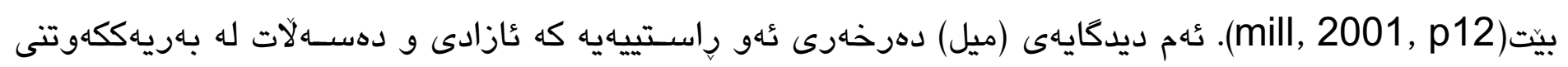

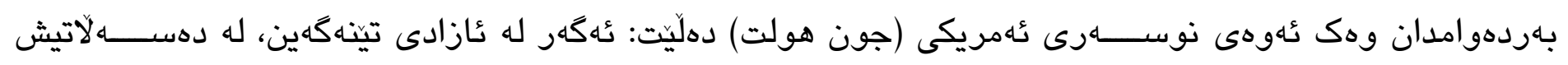

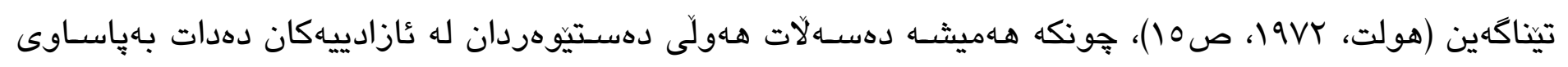

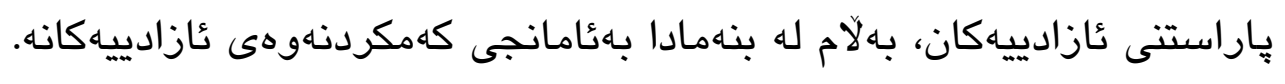

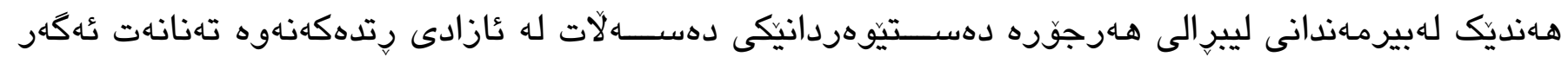

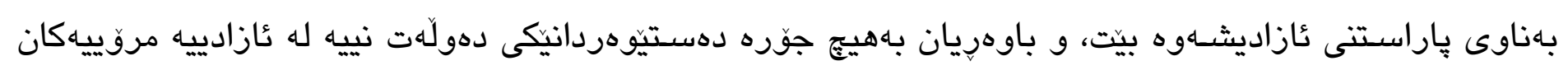




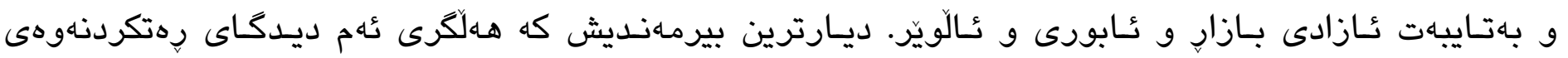

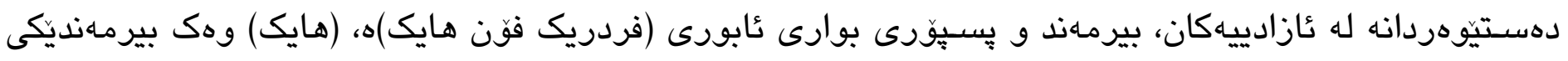

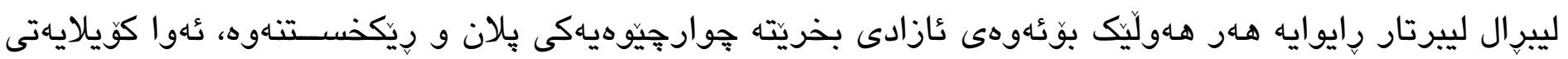

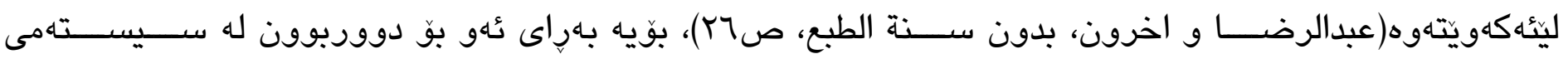

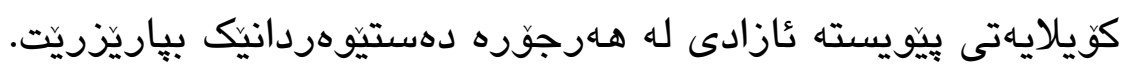

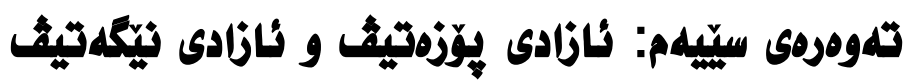

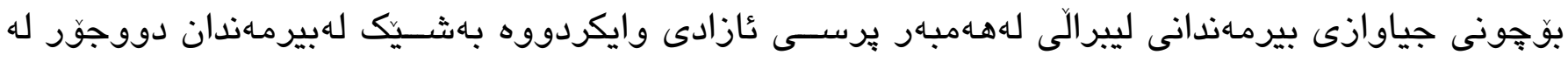

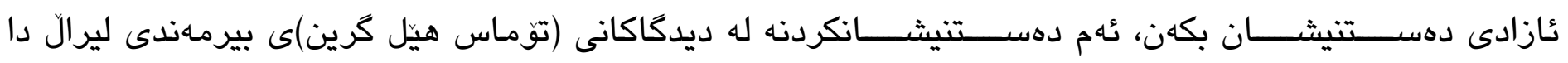

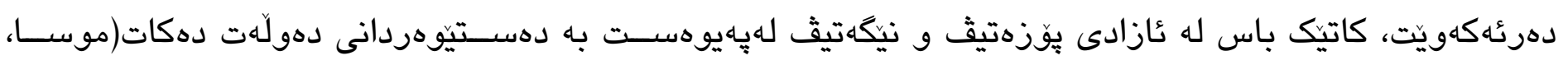

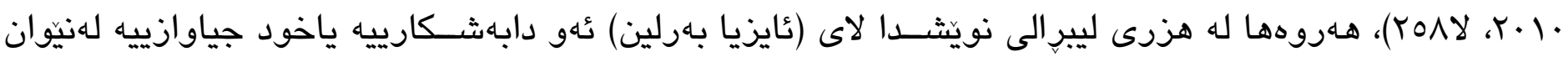

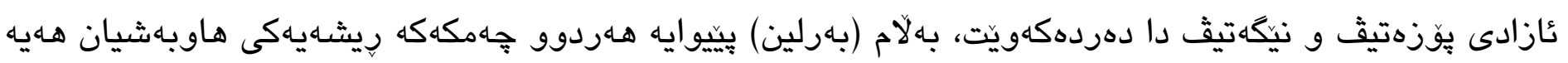

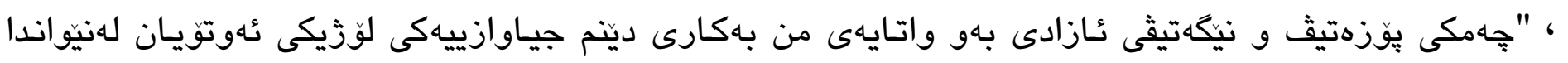

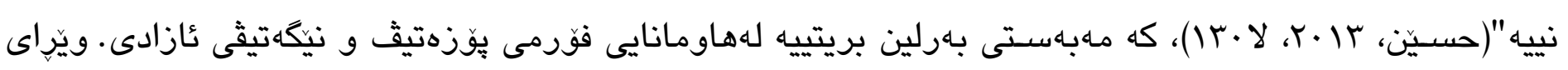

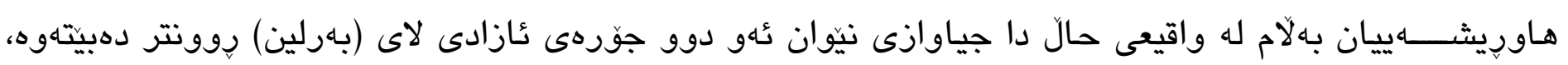

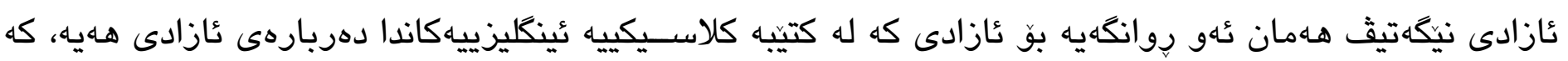

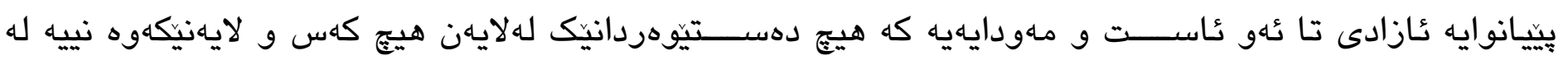

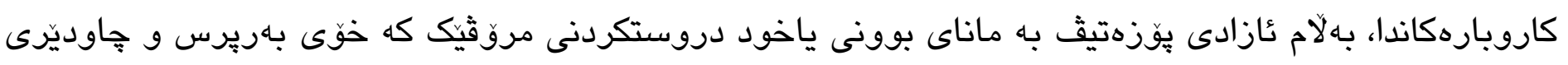

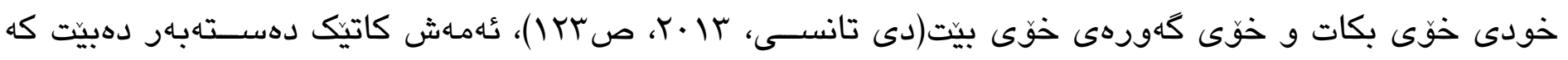

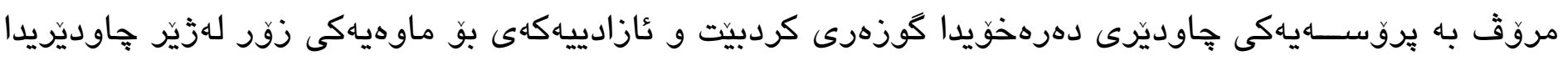

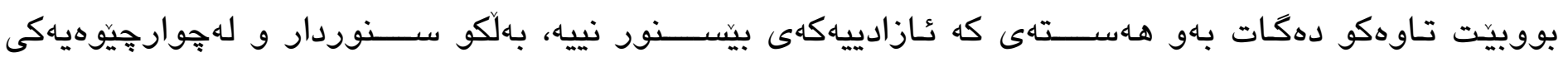

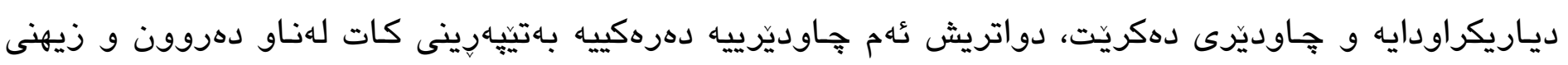

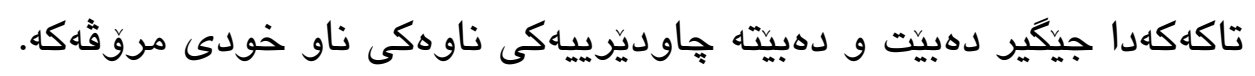

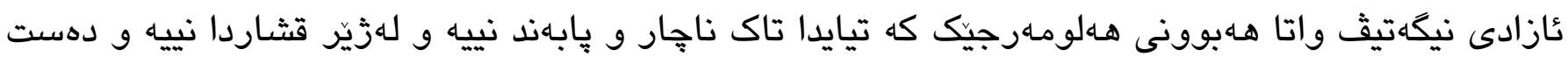

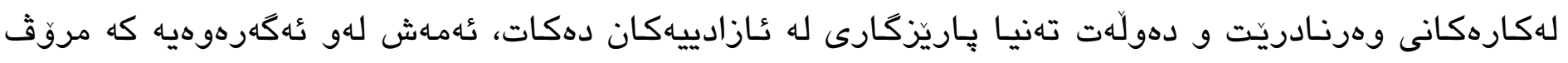

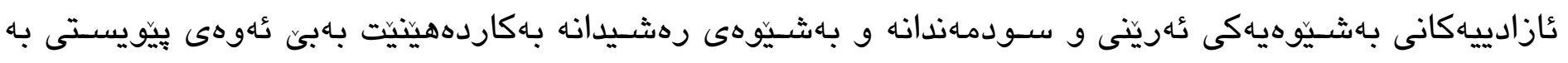

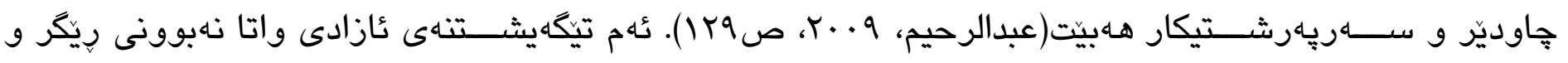

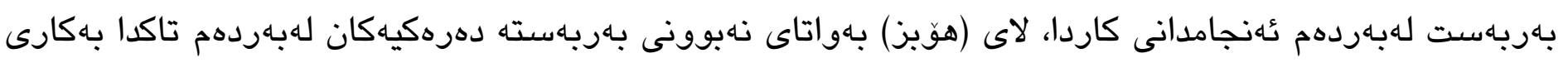


دهبريّت و لاى (بهرلين) بهواتاى بواريكديّت كه تيايدا تاك دهتوانيت بهبئ دروسـتكردنى بهربهاسـت لهلايهن ئهوانى

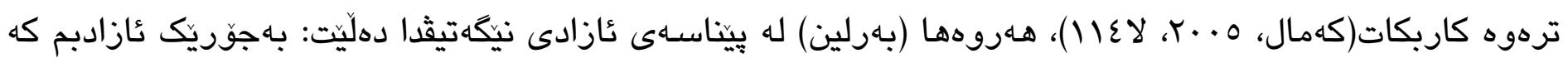

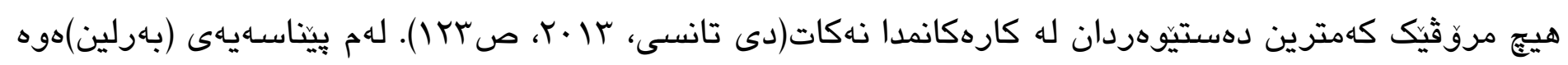

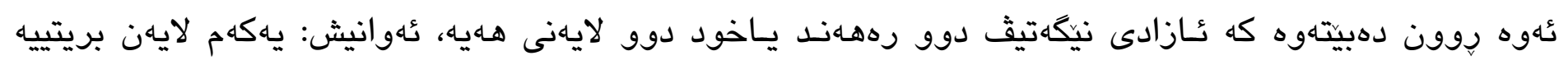

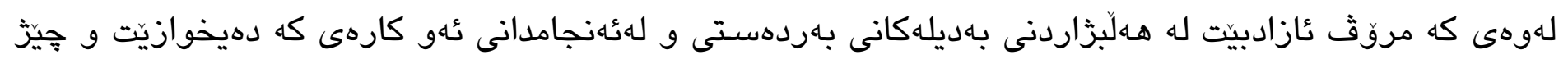

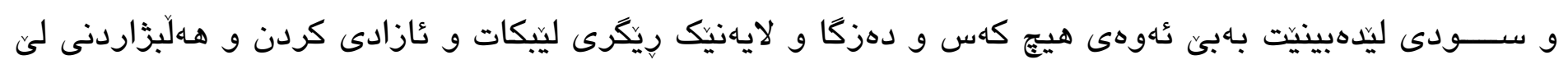

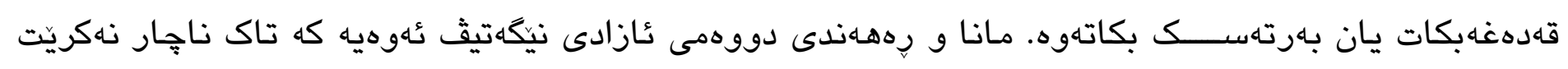

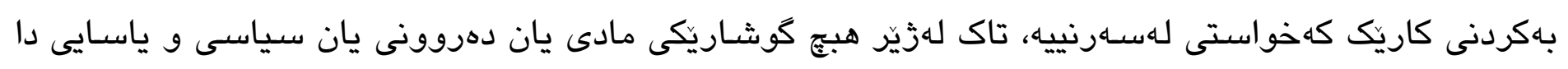

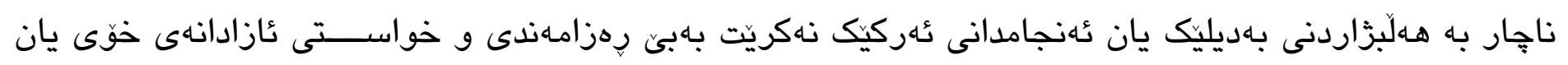

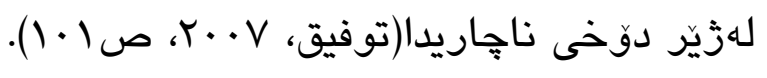

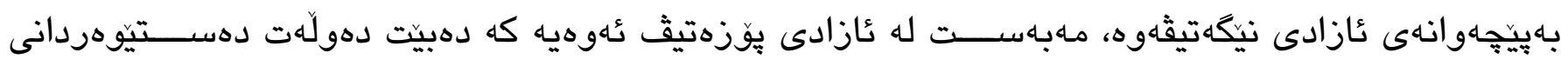

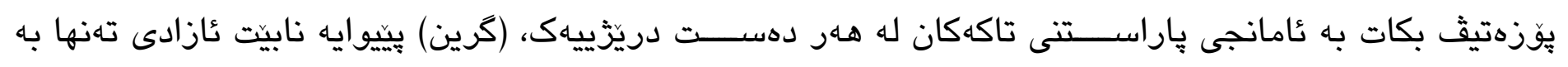

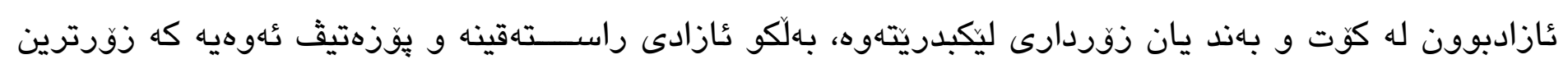

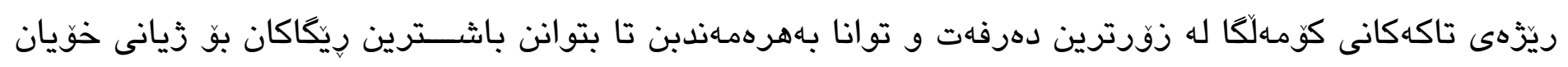

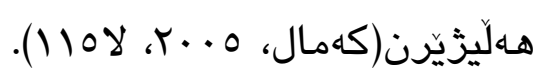

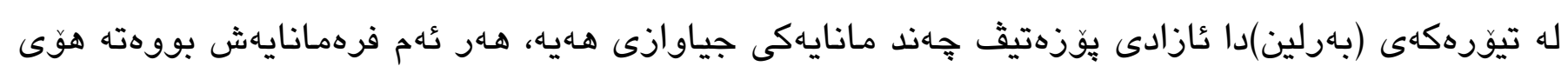

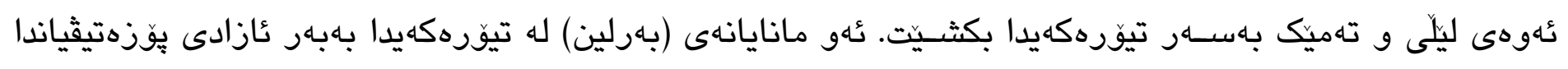

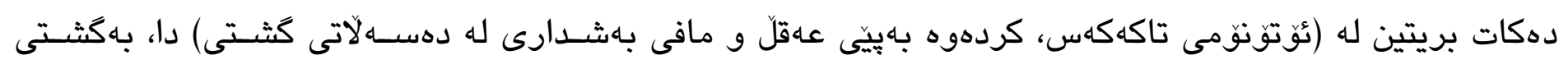

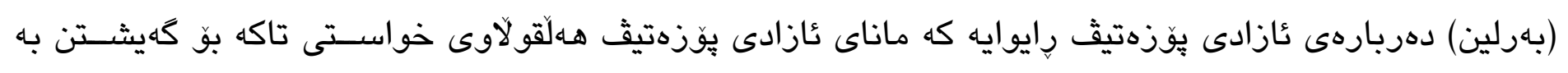

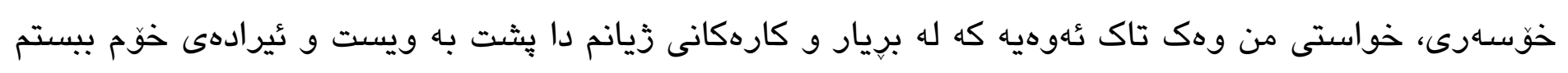

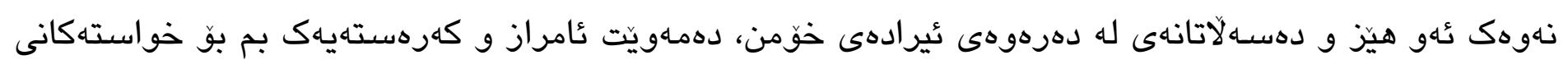

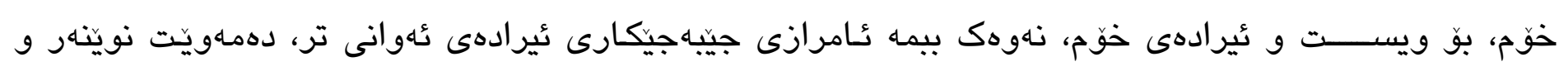

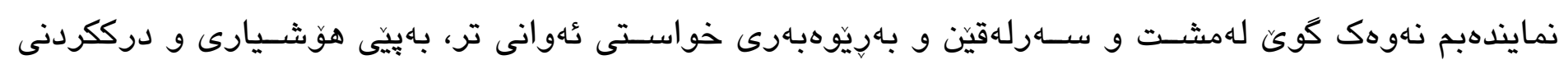

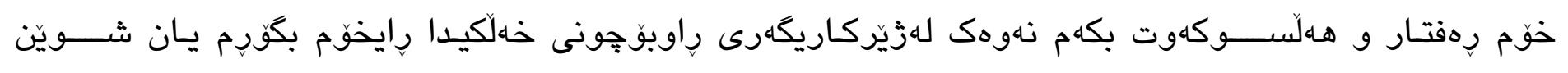

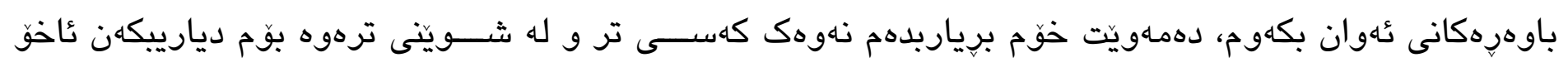

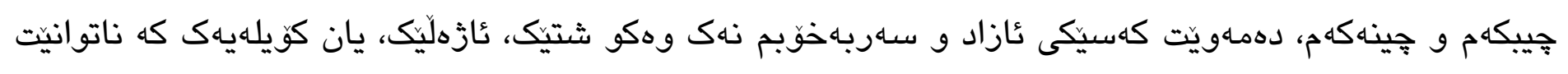

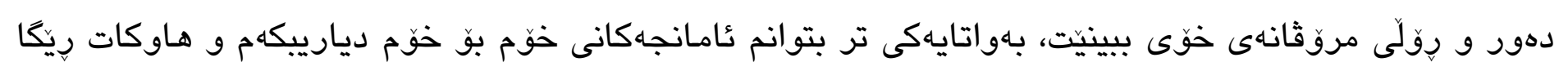




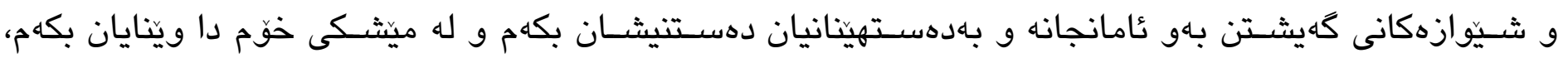

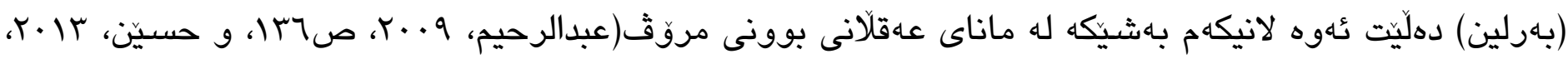

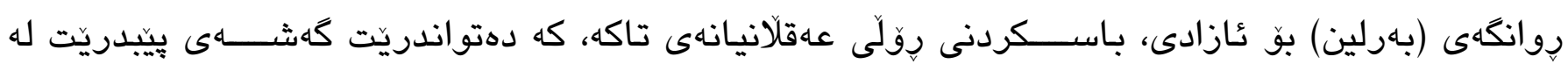

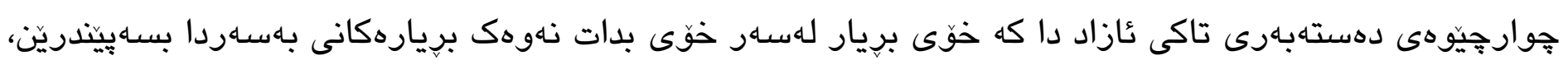

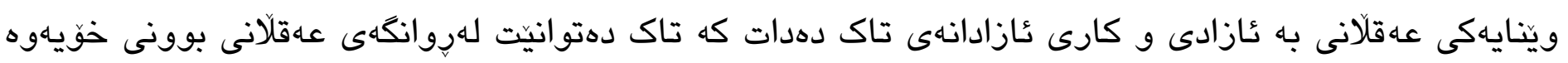

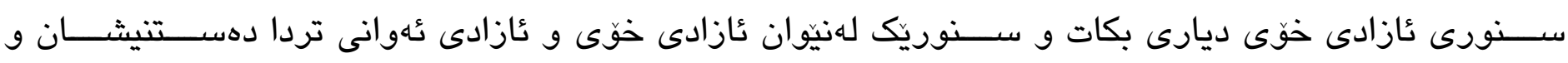

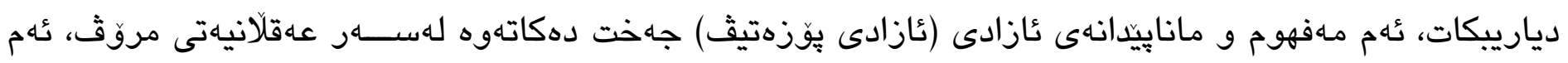

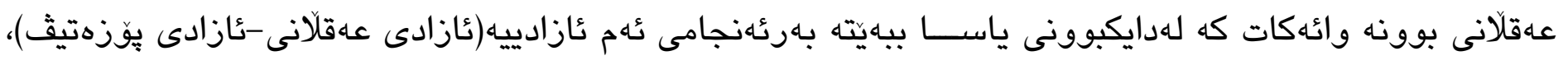

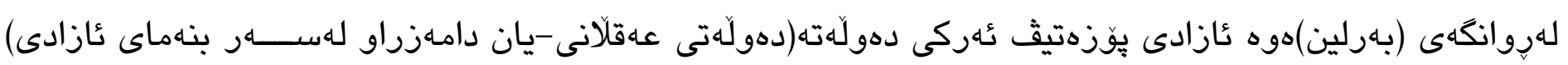

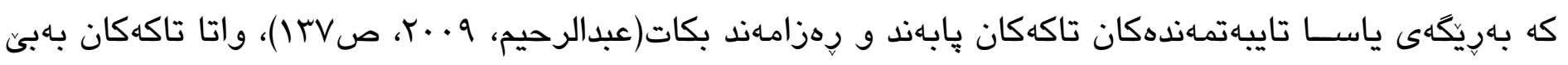

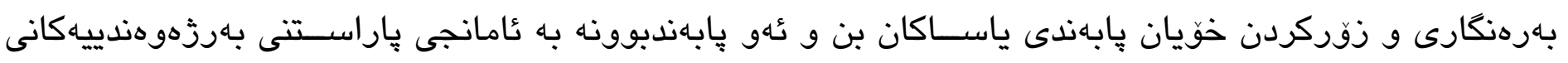

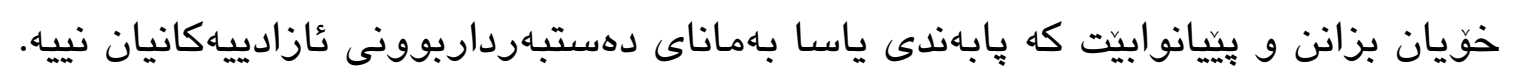

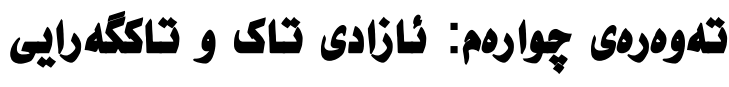

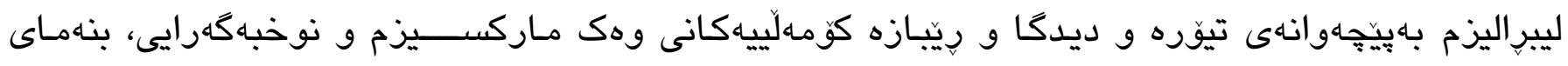

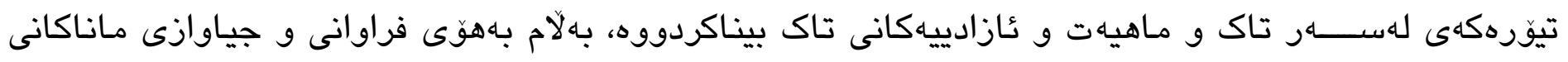

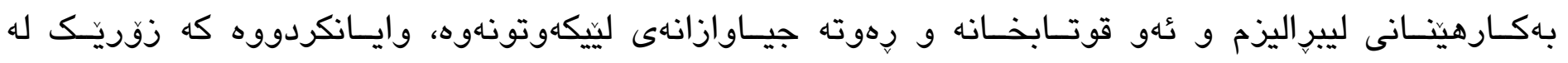

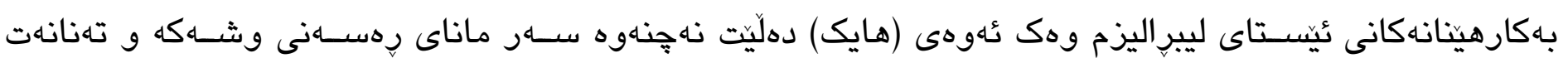

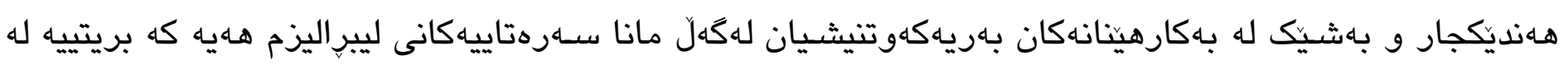

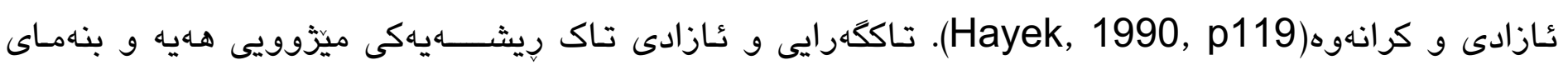

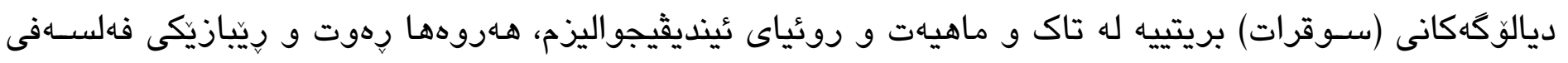

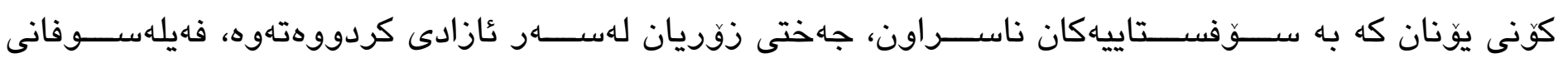

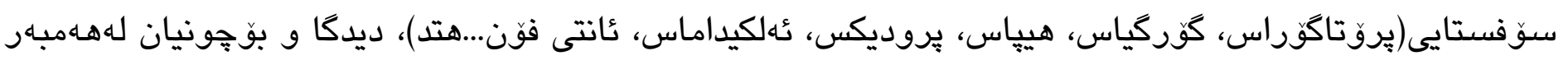

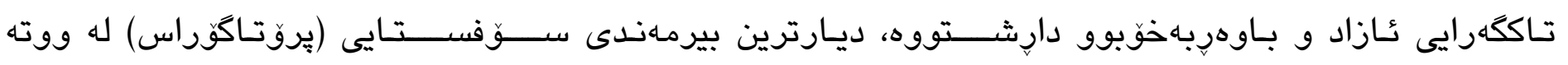

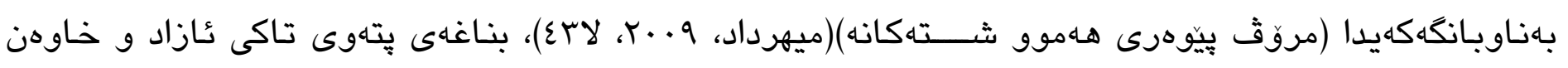

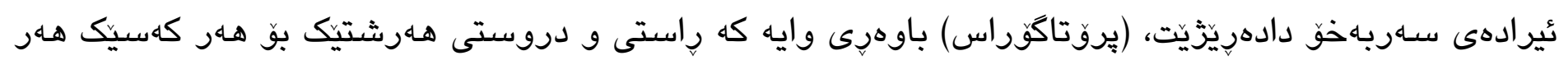




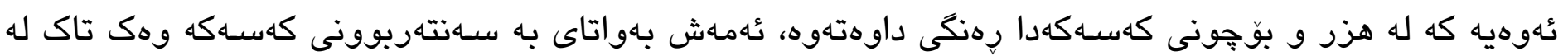
يروّسهـهدا ديّت.

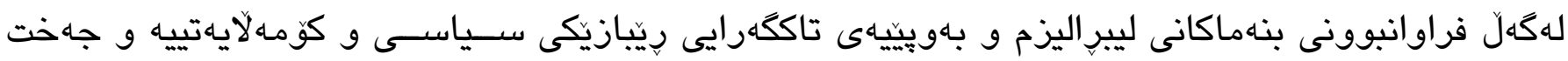

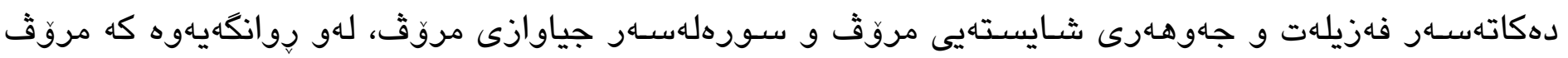

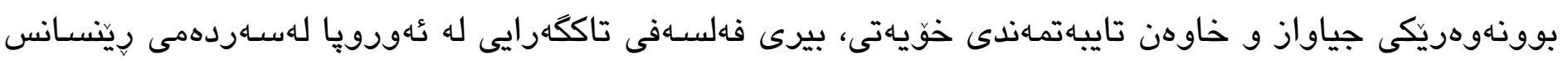

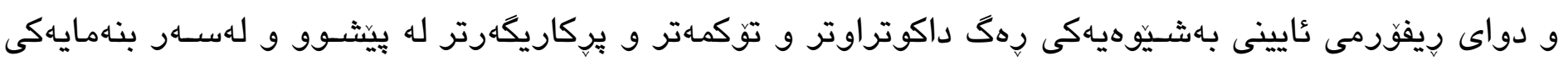

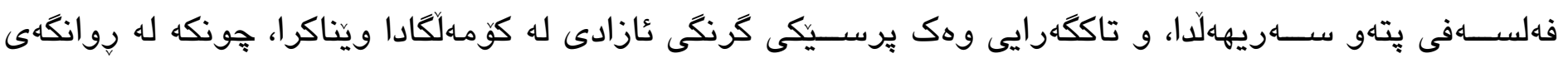

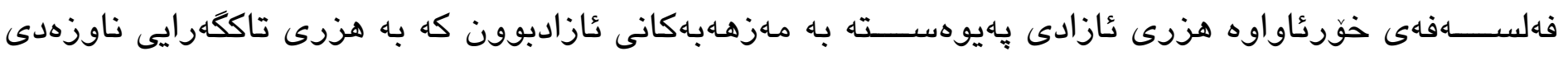

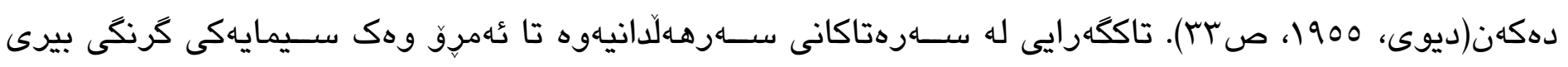

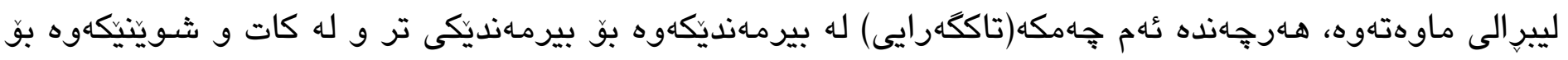

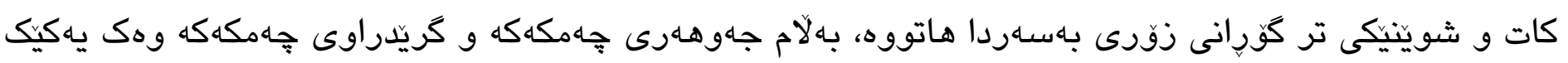

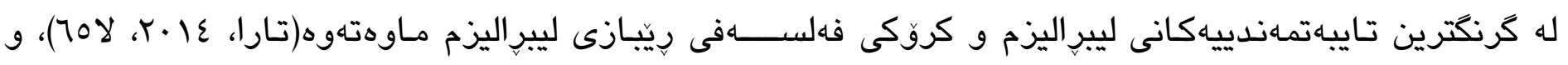

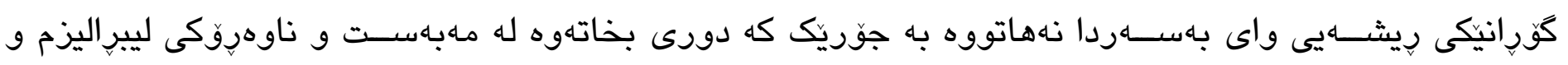
خواسته تاكگَهر اييهكهى.

تاكگهرايى وهك بنهمايهكى كرنگى ليبراليزم لهسـهـر دهسـتى (كرين)، بيرمهندى ليبرالى و ديارترين بيريارى

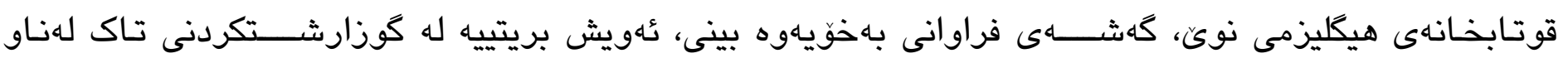

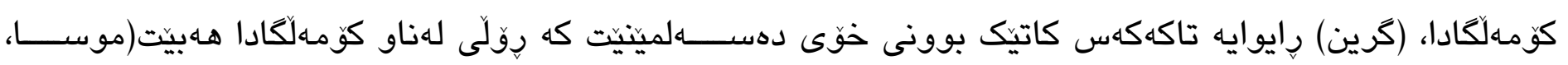

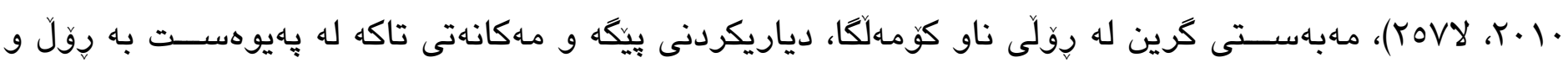

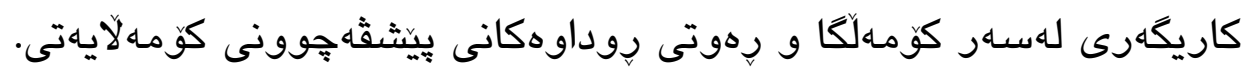

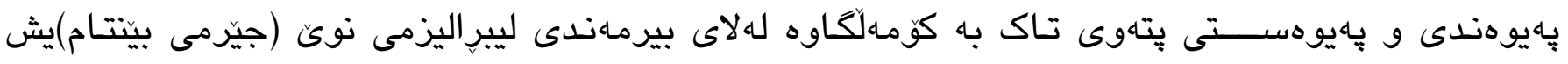

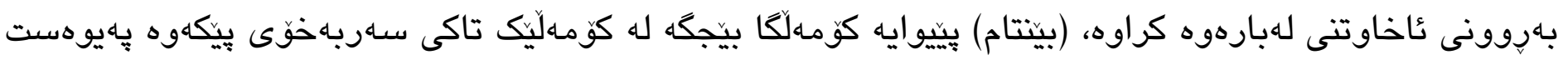

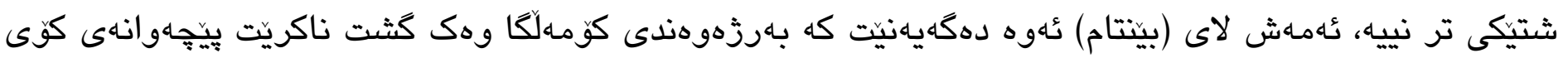

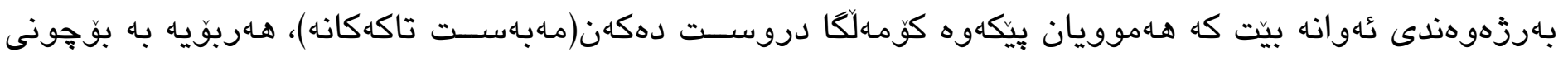

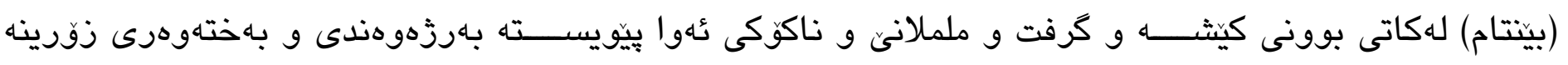

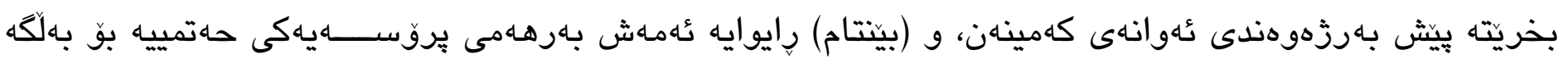

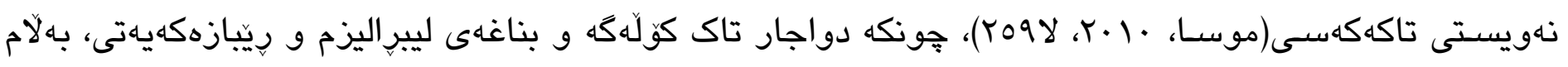

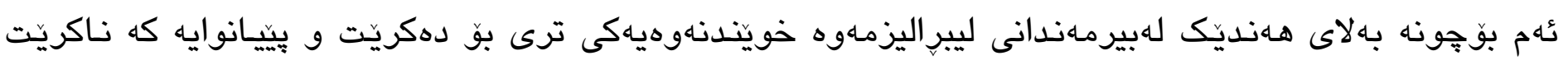




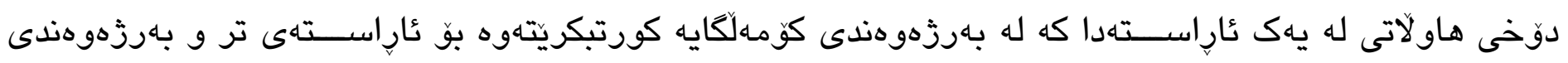

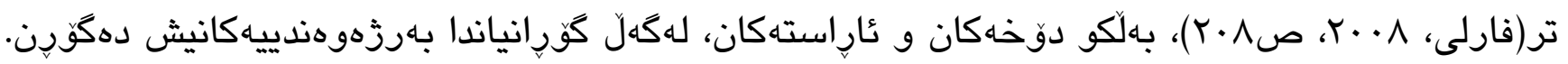

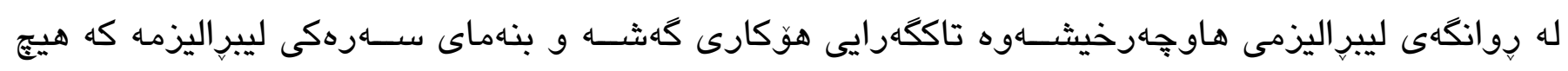

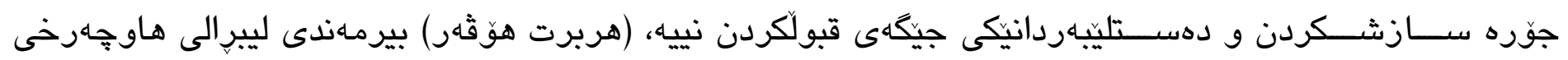

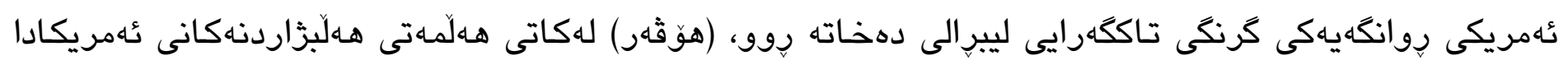

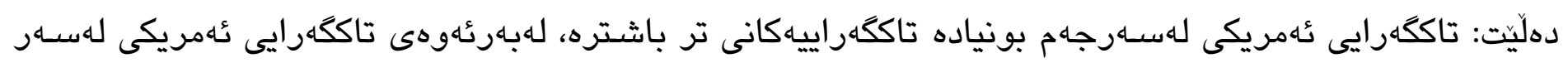

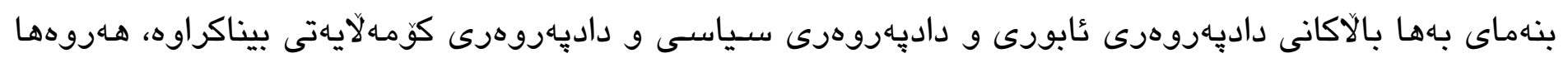

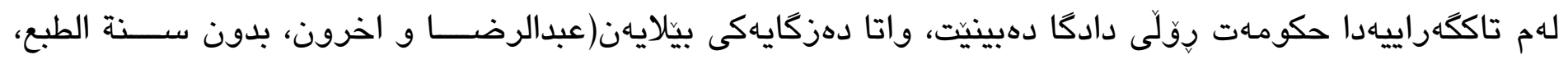

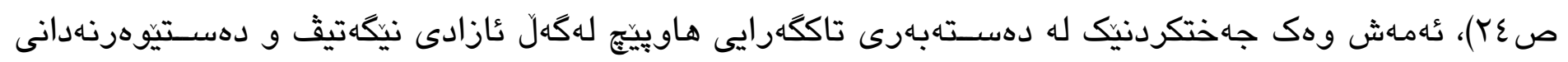

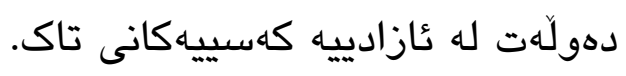

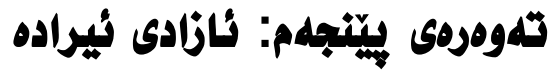

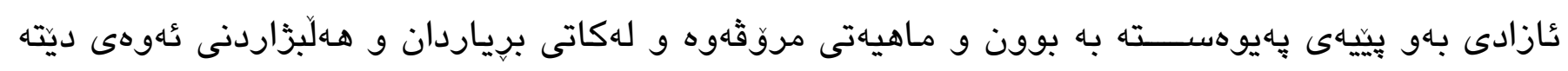

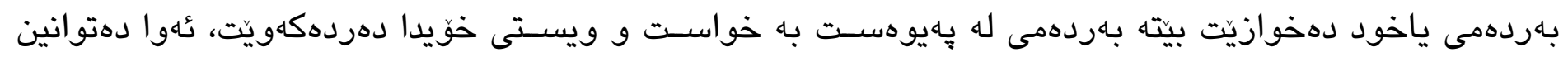

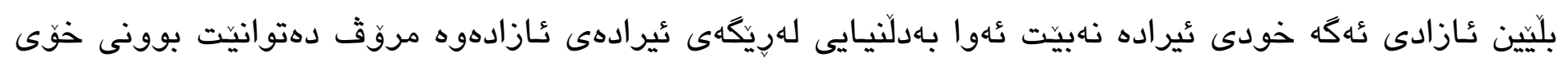

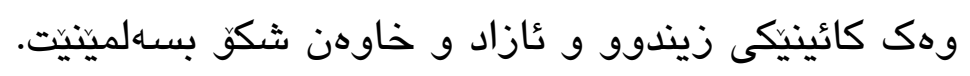

فهيلهسوف و دهروونتاسى ئينكليز(وليهم جيمس) عازادى مروقيى له ئازادى ئيرادها دهبينيت و يِييوايه يهكهم

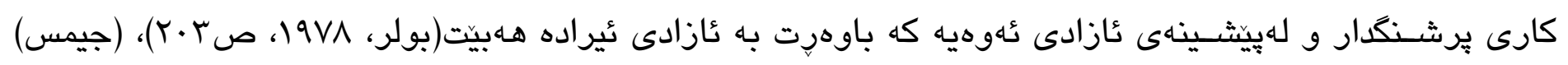

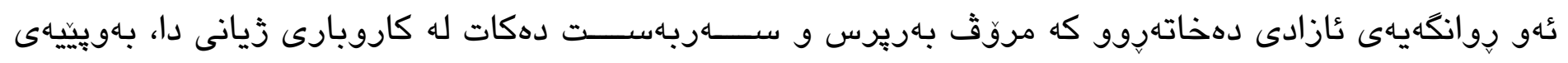

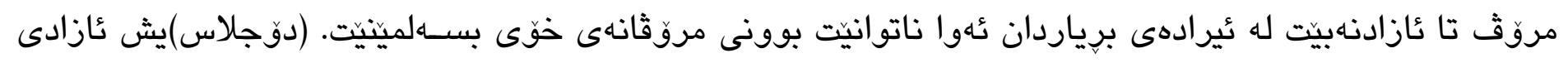

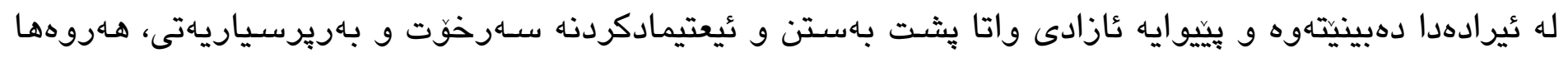

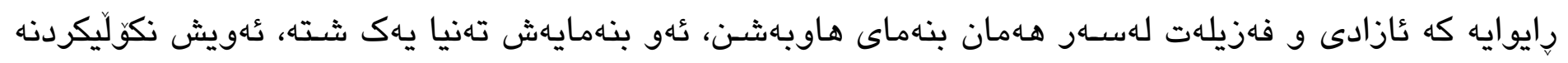

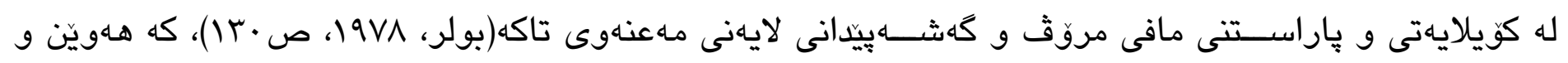

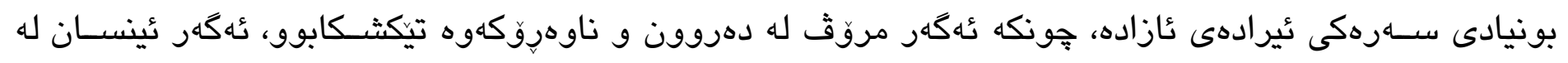

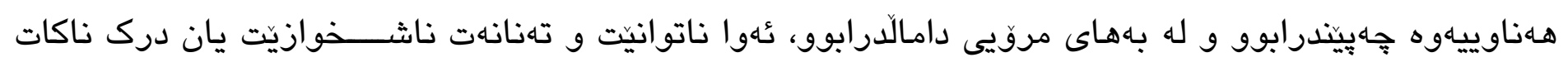

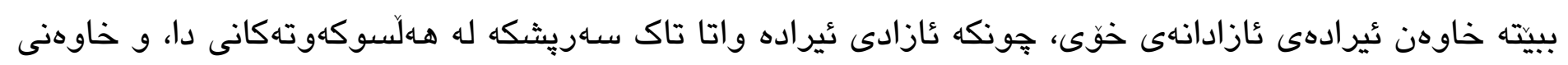

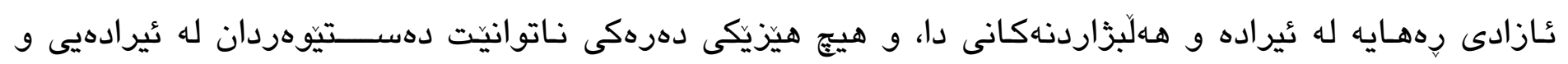




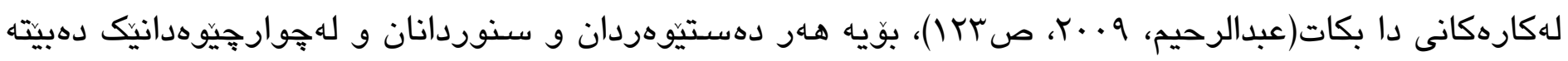

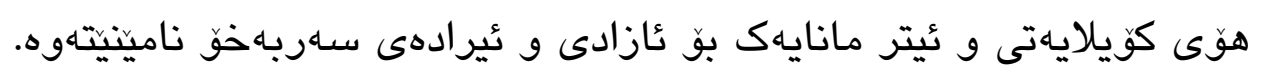

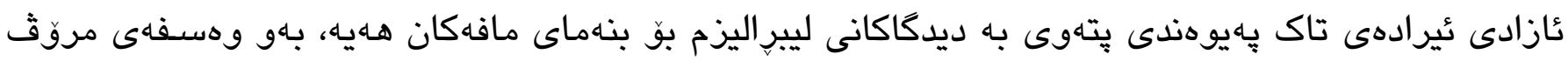

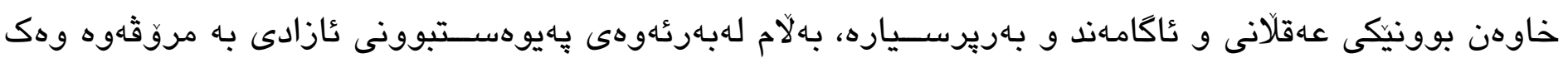

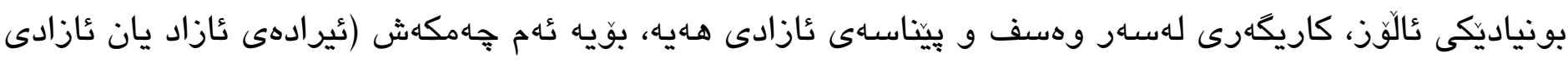

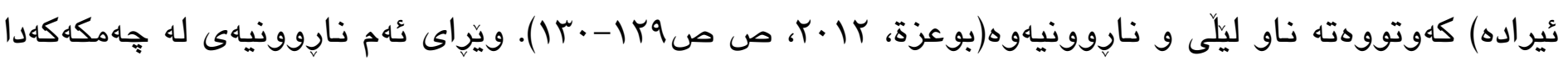

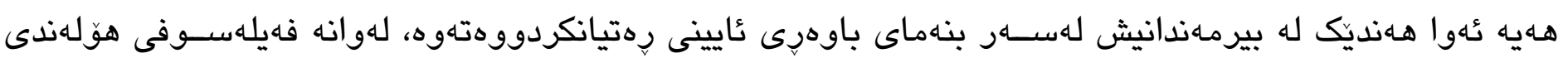

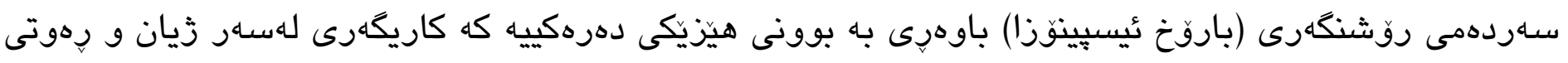

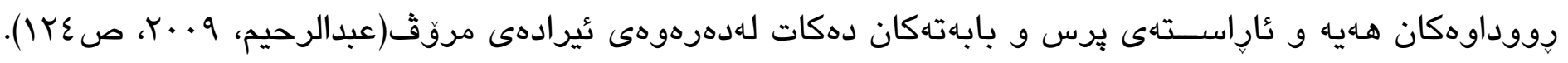

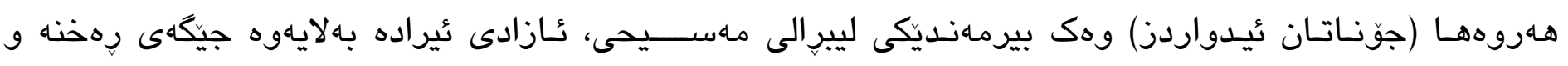

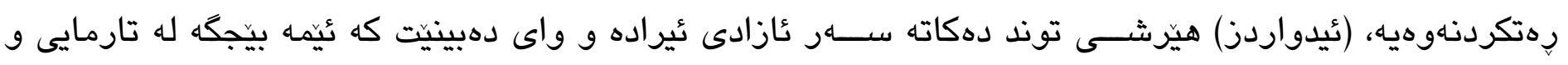

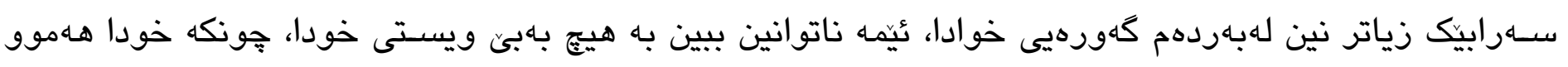

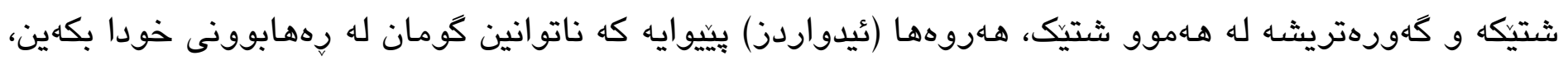

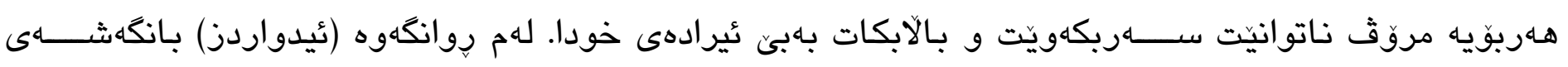

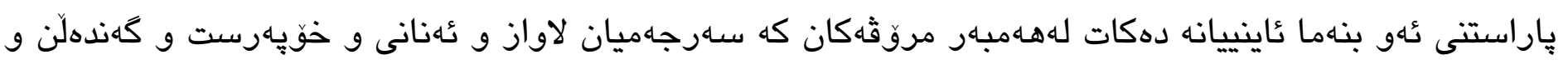

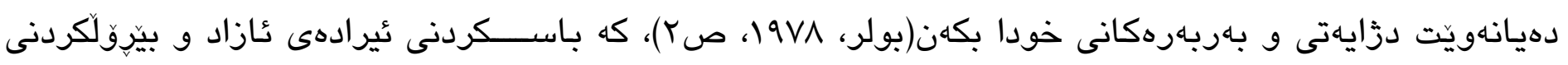

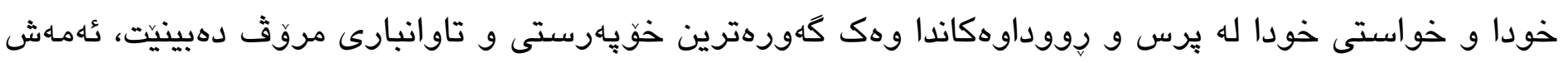

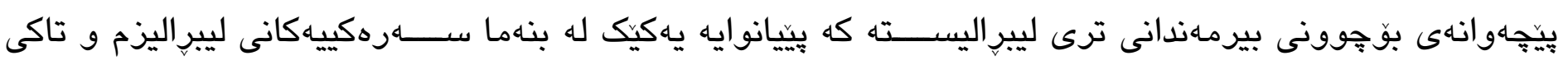

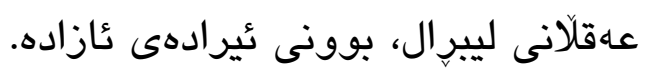




\section{باسى دووهم}

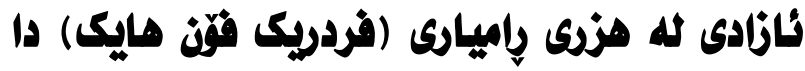

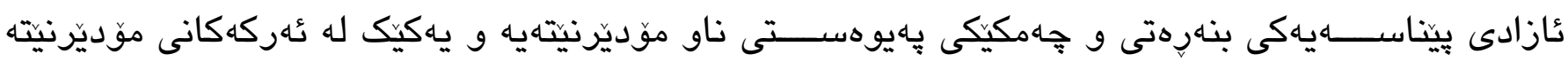

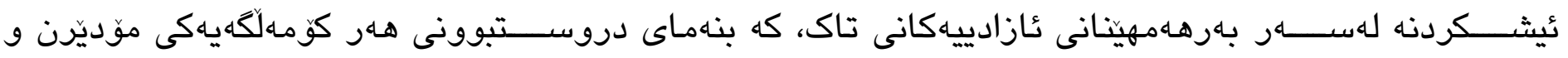

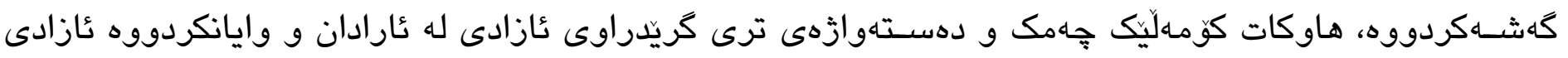

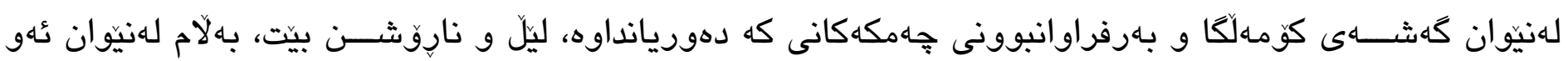

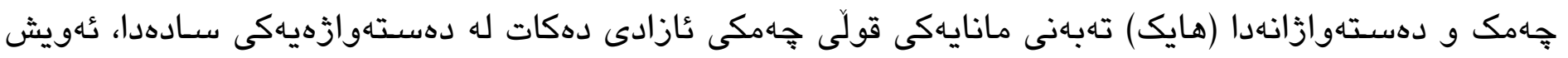

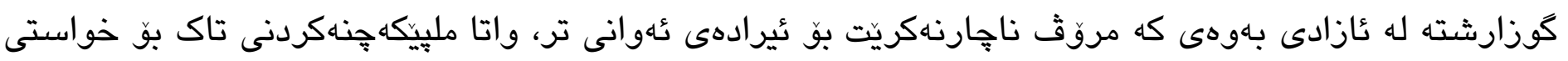
كُهوانى تر(feedo, 2018).

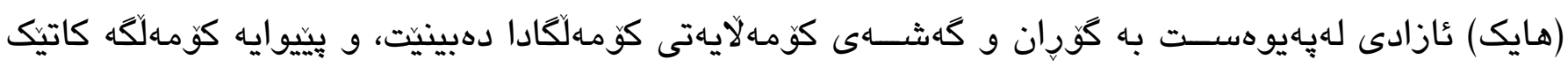

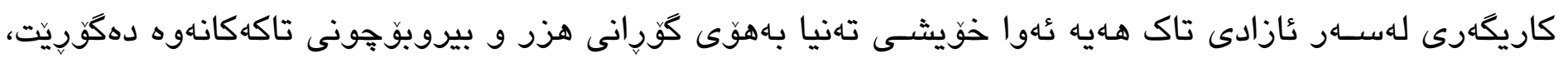

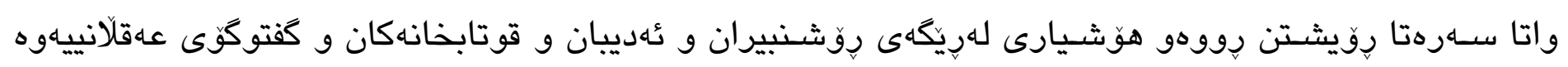

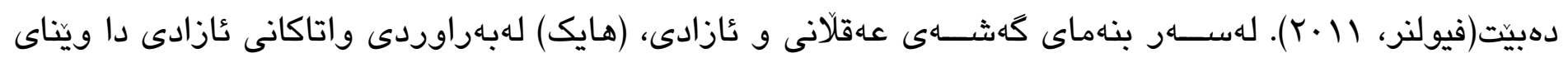

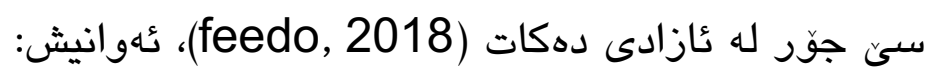

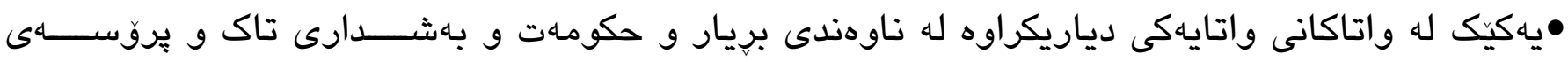
ياسـادانان و كارويايى كاركُيزىى، (هايك) عُهم جوّره له ئازادى ناودهنيت عازادى سياسى. •ـازادى له واتايهكى تردا بريتييه لـ تُاسـت و مـهوداى تواناكانى تاك بو كَيشـتن به خواسـته كهـيـيهكانى،

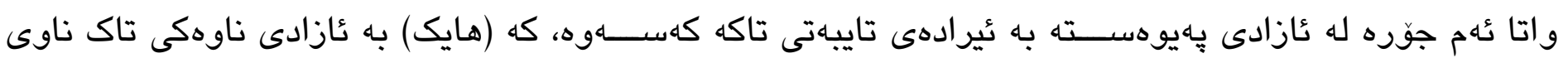
دهبات.

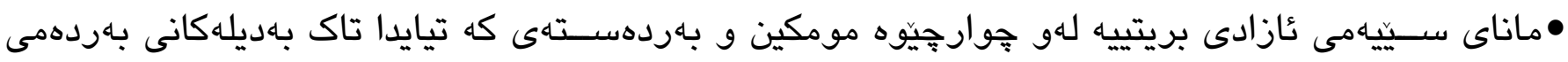

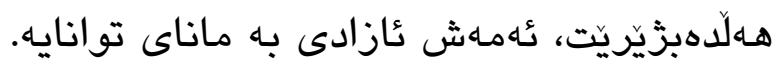

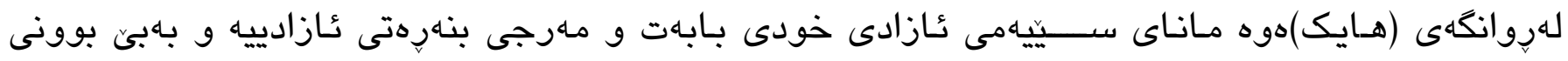
جوارجيّوهيهكى مومكين بوّ دهستهبهرى خواستهكانى تاك ئهوا جوّرهانى ترى ئازادى مانايهكى ئهوتق بو بوونيان

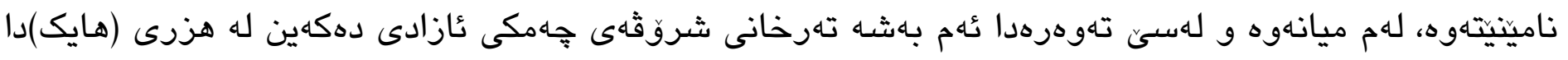
كه تيايدا يرسى داديهروهرى و ئازادى نيّكَتيق و عازادى كارو مولكايهتى شـهنوكهو دهكهين. 


\section{تلهوهروى يلهكم: نازادى يان داديهروهرى!}

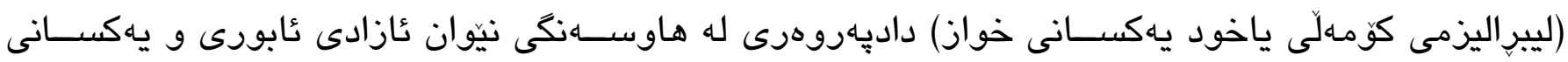

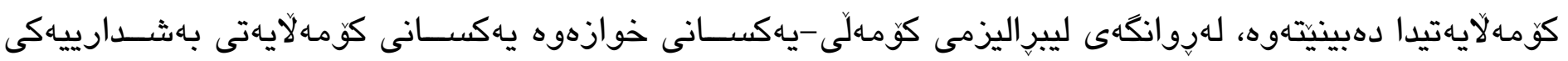

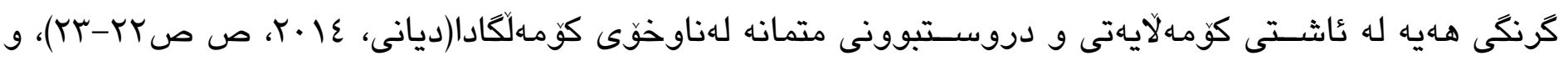

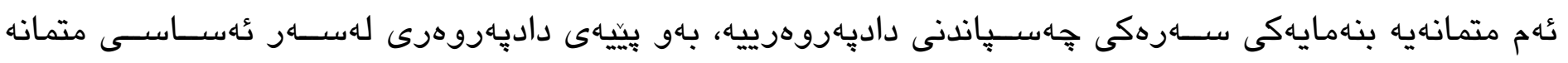

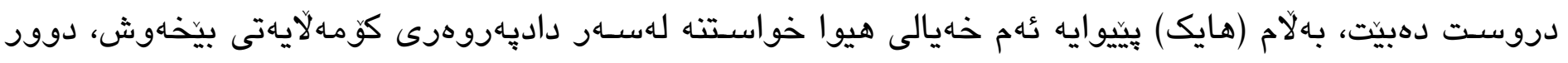

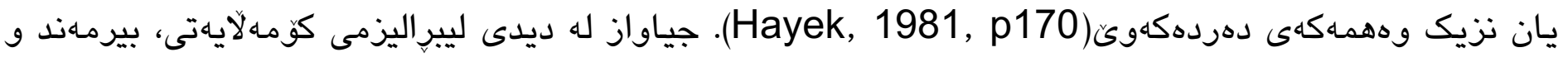

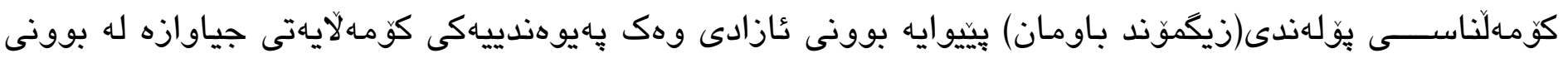

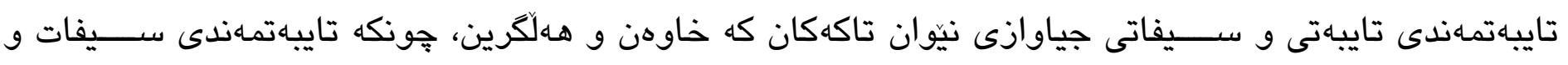

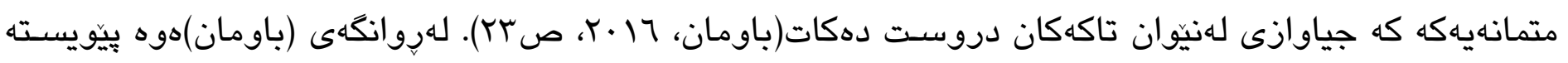

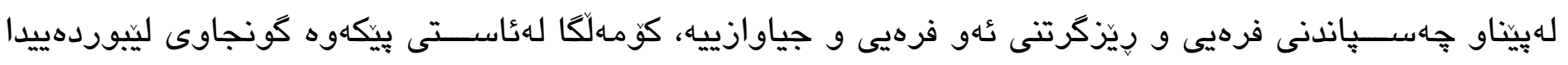

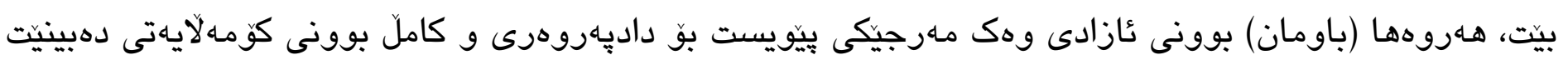

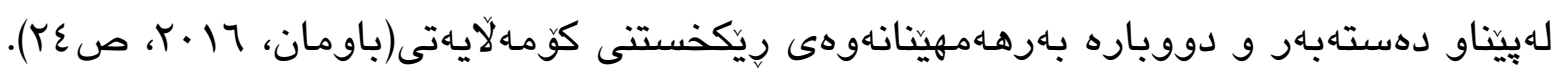

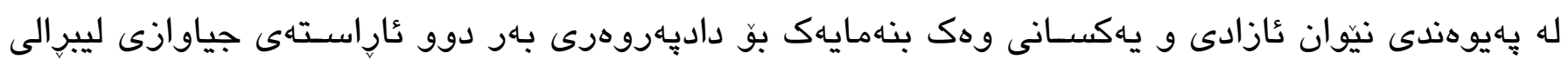

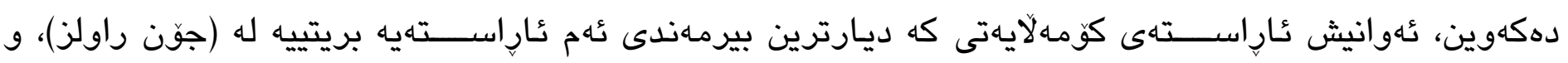

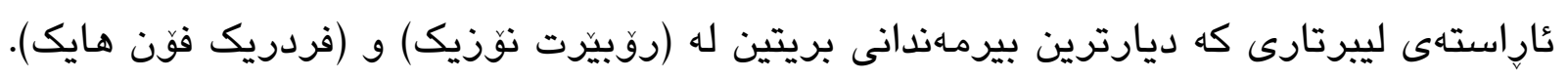

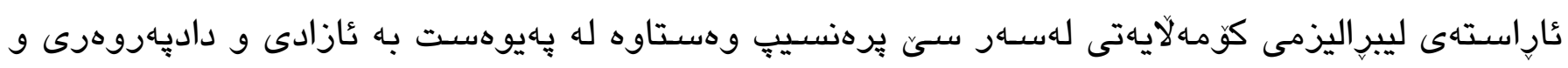

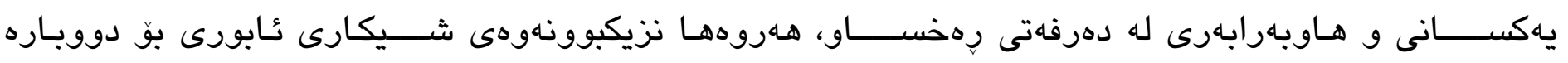

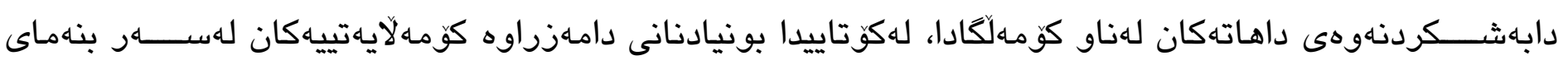

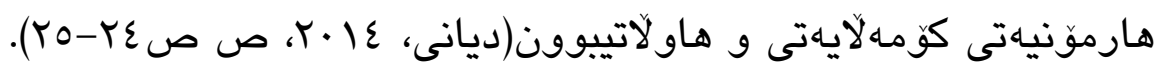

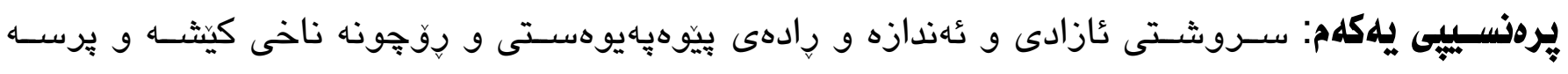

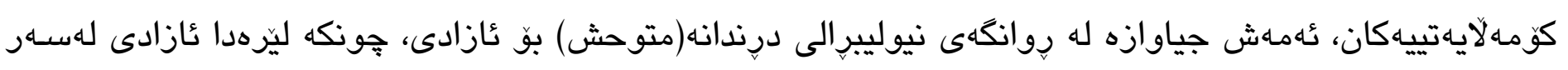

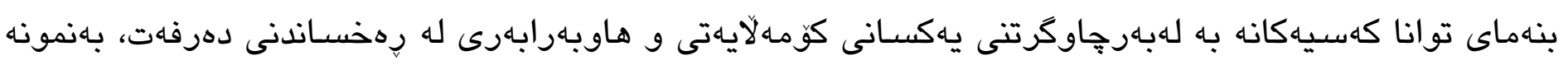

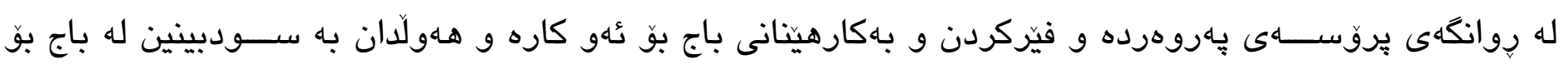
خزماهتى پِّروهرده و تهندروستى كثنتى. 


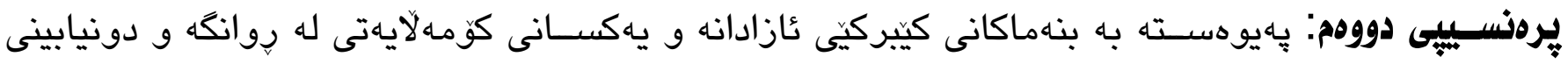

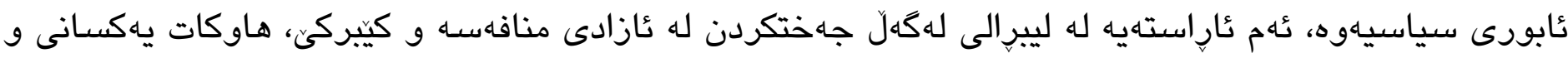

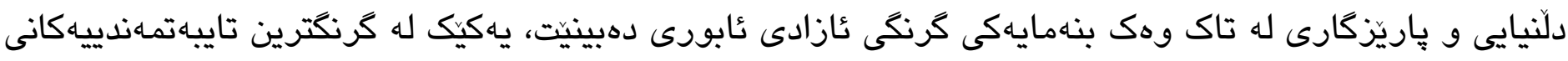

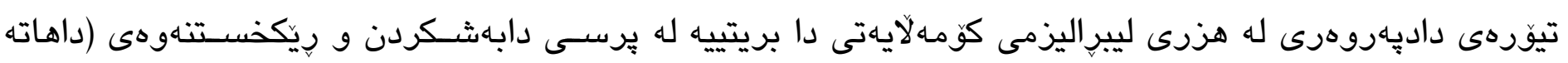

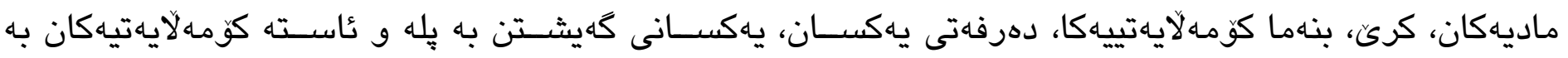

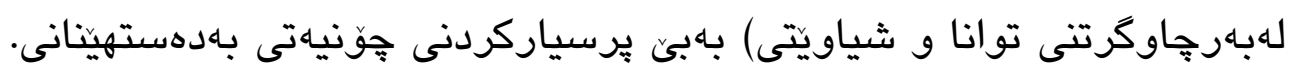

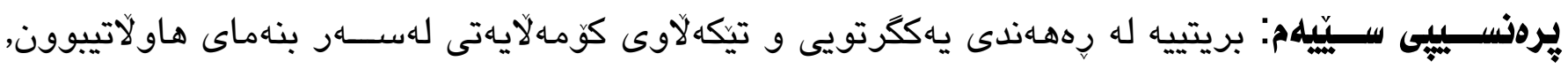

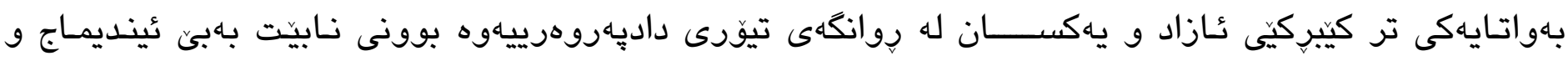

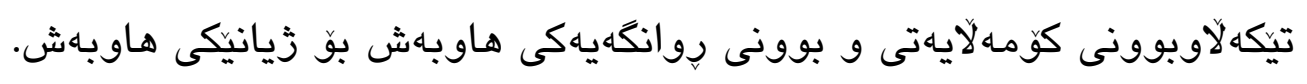

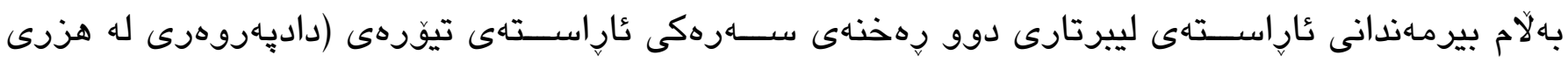

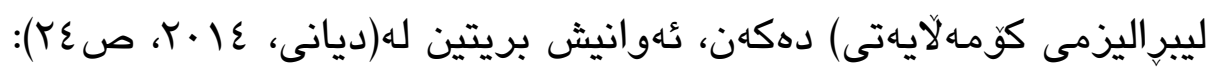

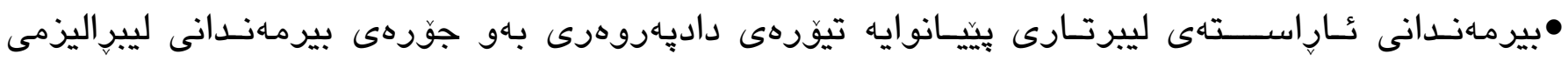

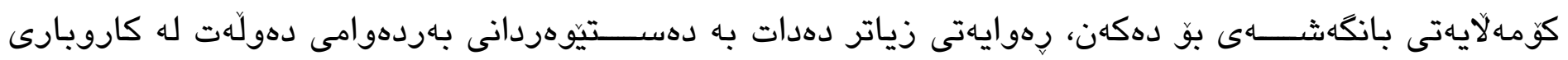

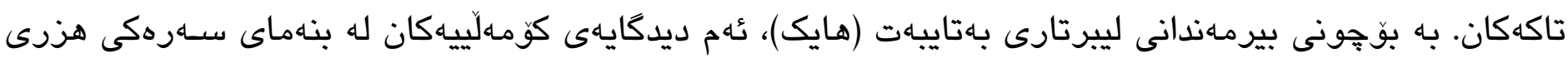

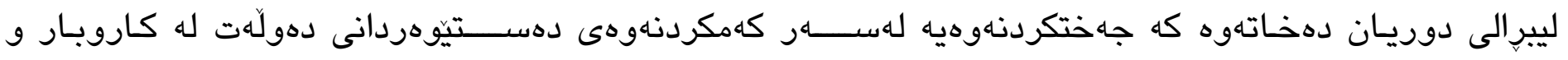

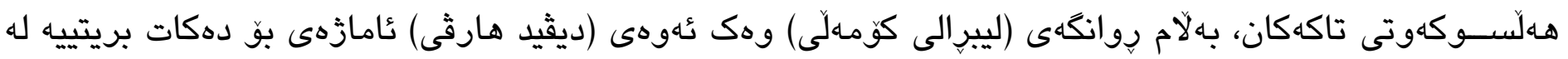

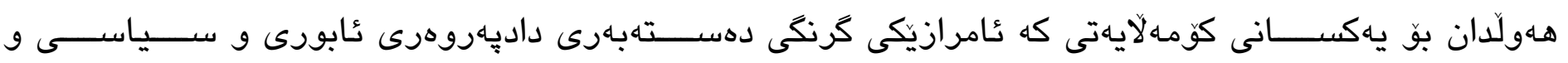

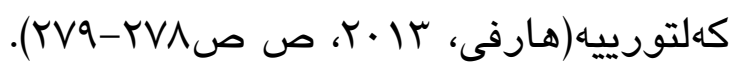

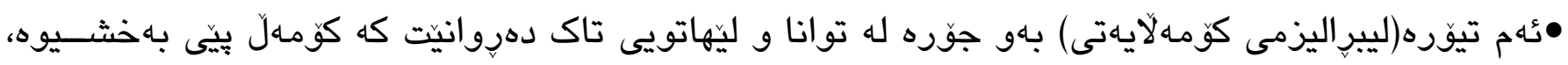

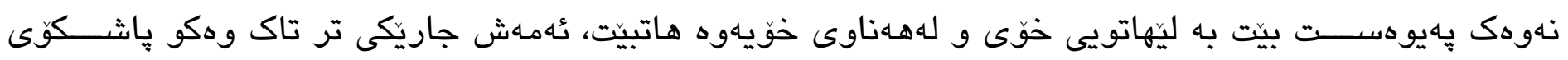

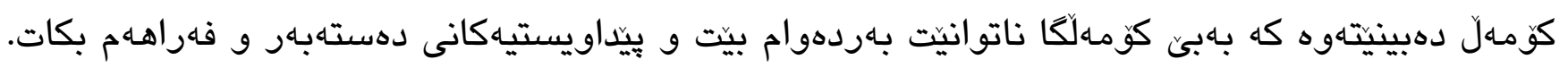

لهروانكاهى (هايك)هوه داديهروهرى بِهيوهنديدار نييه به بِرهنســيِيى ميتافيزيكى يـان ئهخلاقى وهك ئهوهى

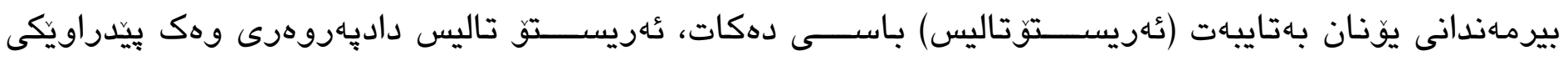

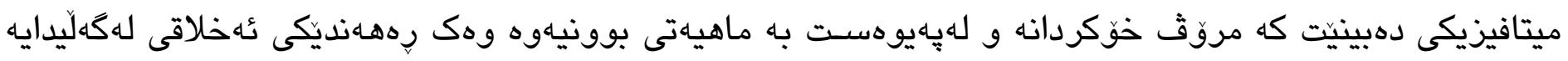

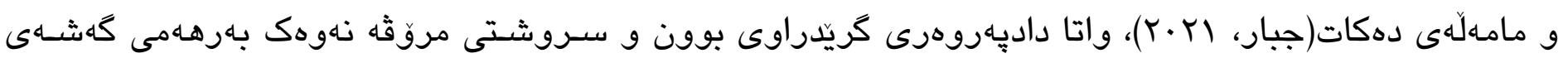

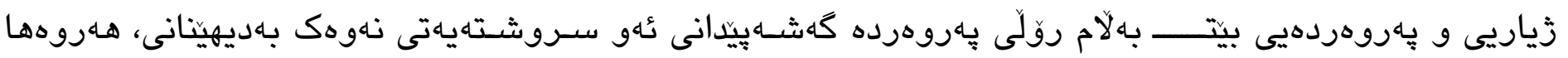




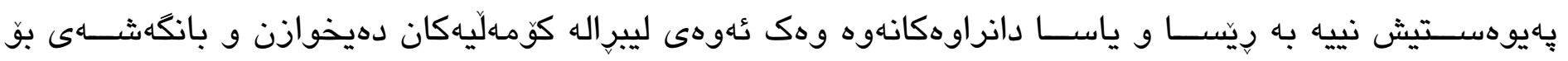
دهكهن، بهلكو كردهى داديهروهرانه له بـراورد به كردهى ســـتهمخهرانها دهردهكهويّت، واتـا بـارودوخهكان له

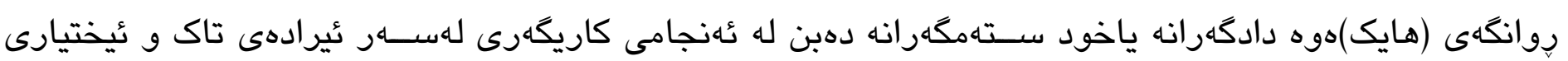

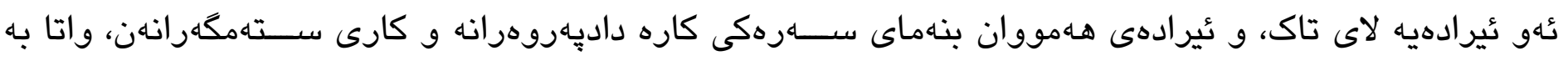
هـاهوونى (ئازادى ئيراده) هـه داديهروهرى و هـهيش ســتهم ئاماده دهبيت، و بـ نهبوونى ئيرادهى ئازاد، ئهمانيش

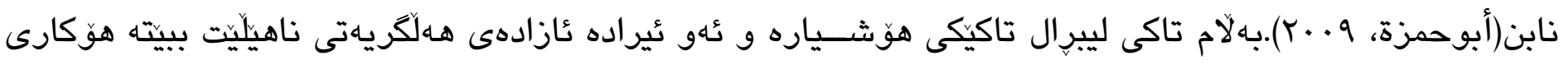

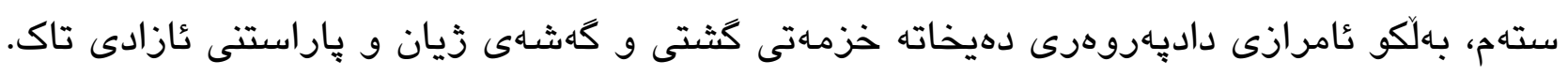

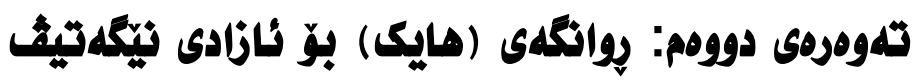

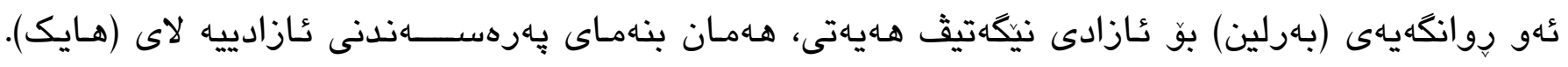

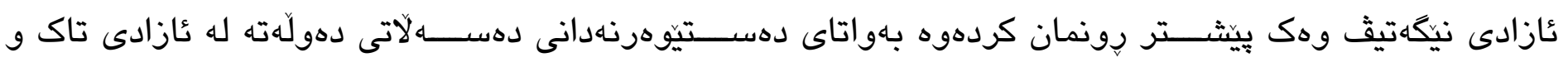

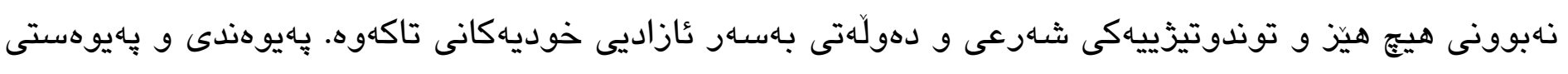

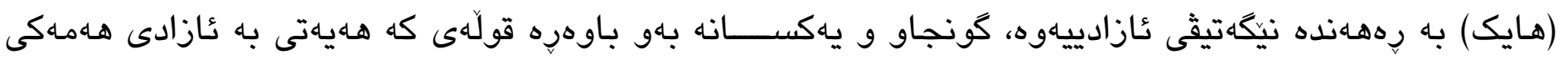

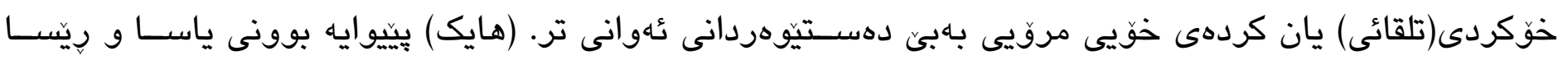

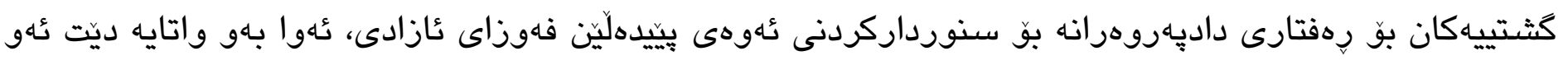

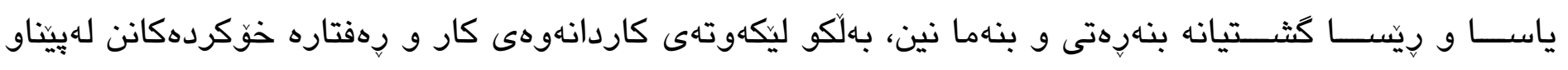

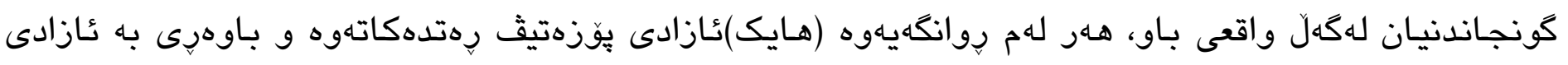

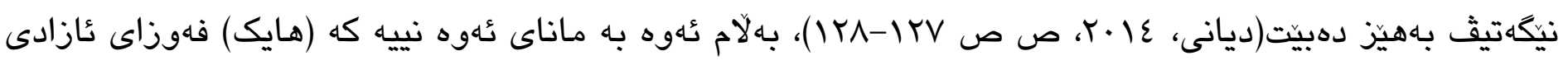

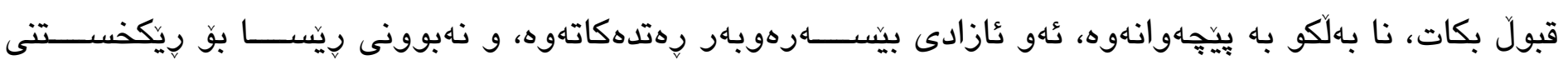

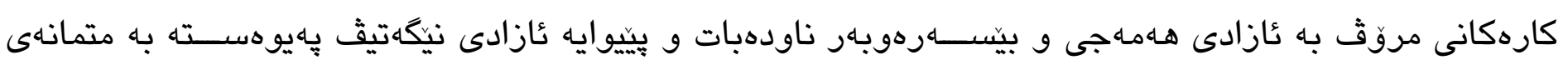

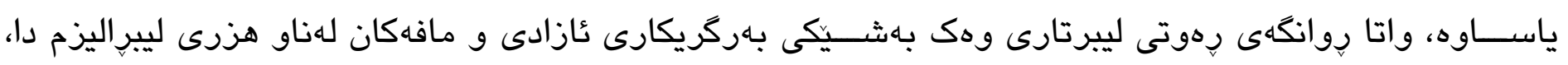

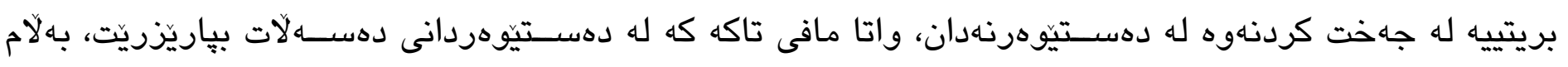

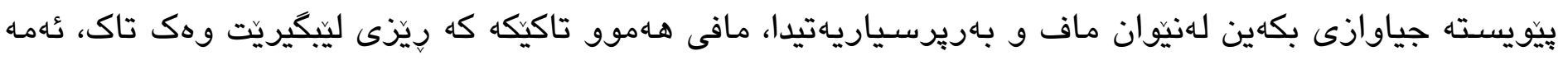

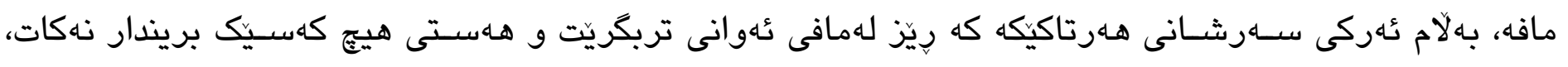

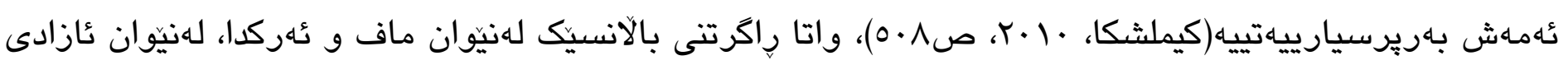

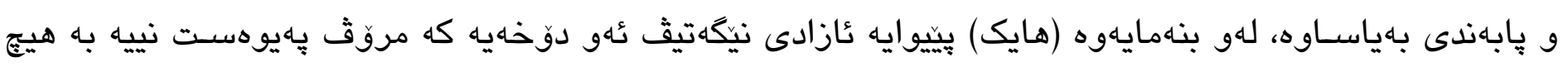

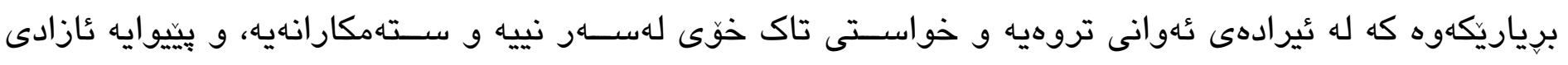

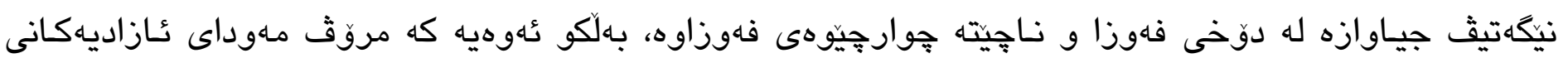




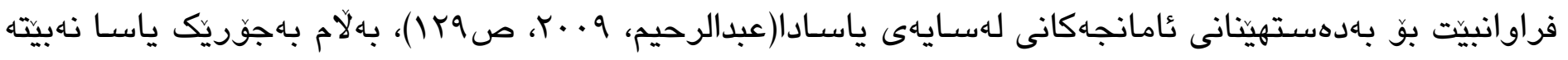

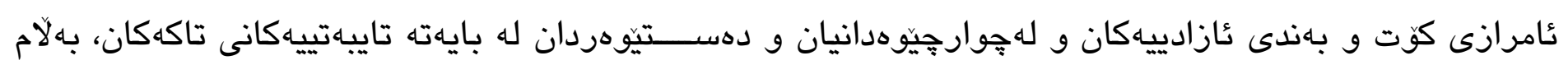

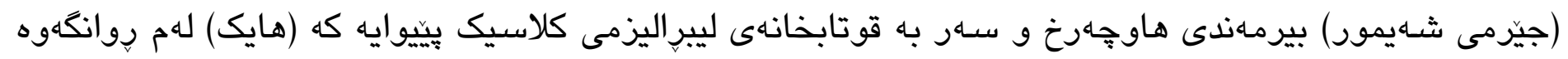

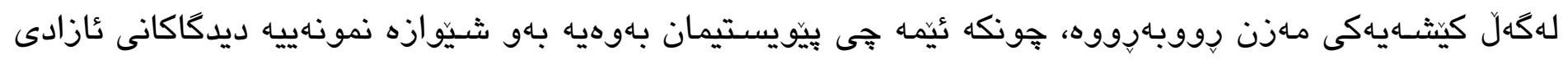

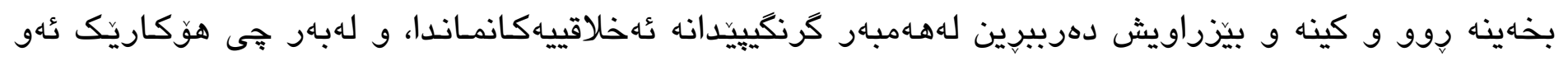

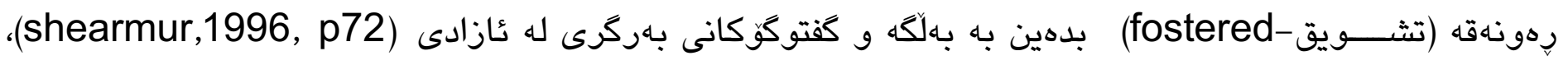

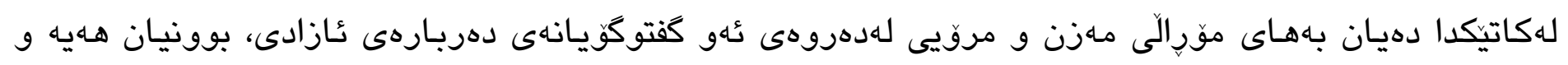
بيّويستى ذيارييشن.

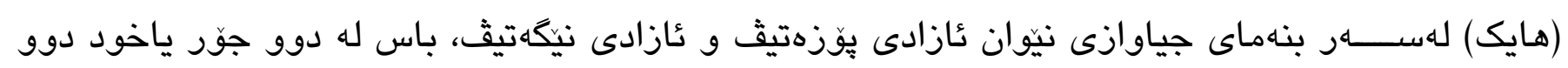

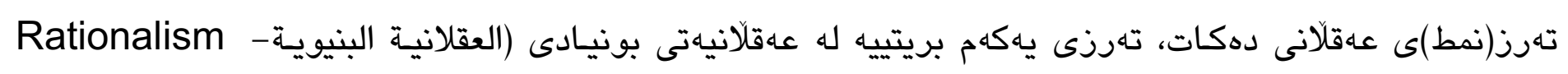
تConstructivist

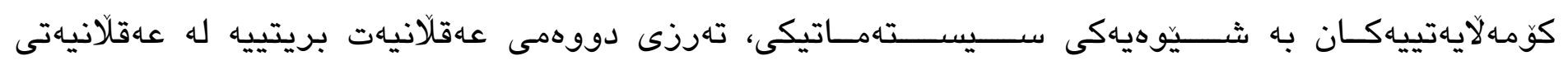

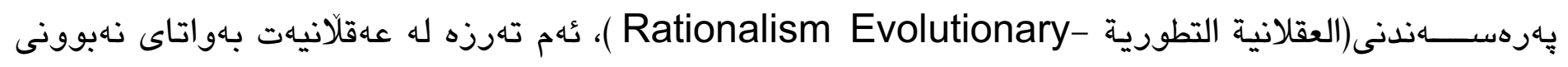

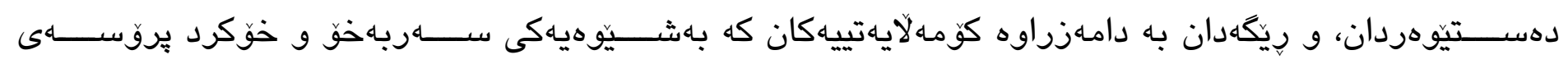

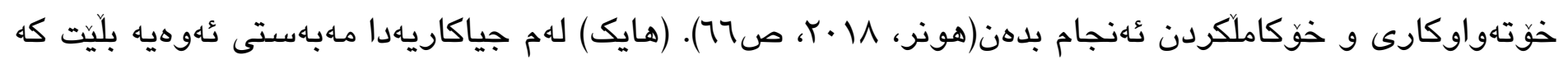

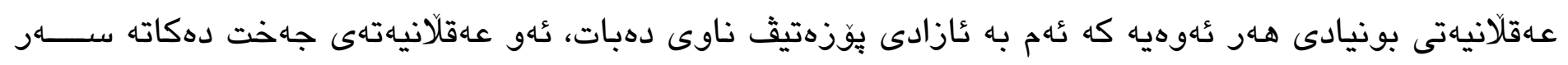

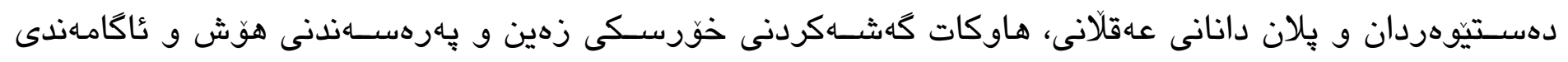

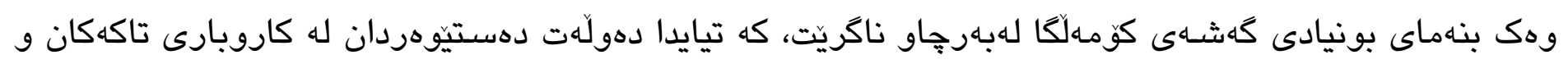

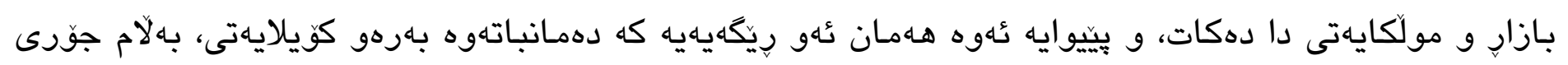

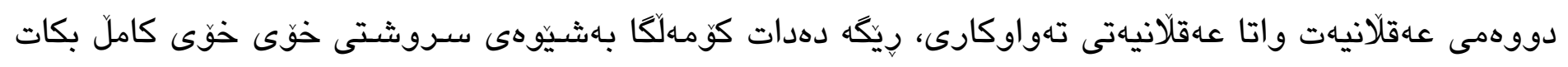

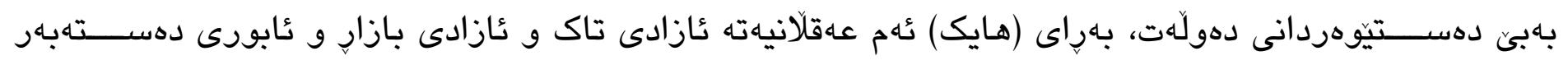

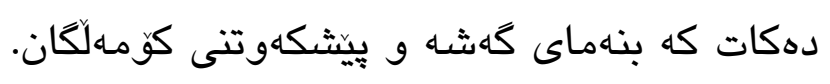

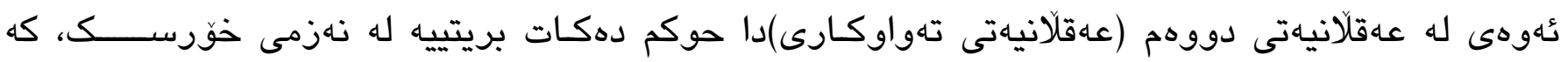

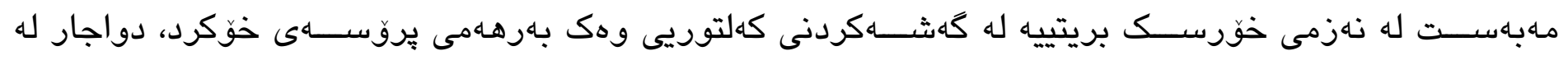

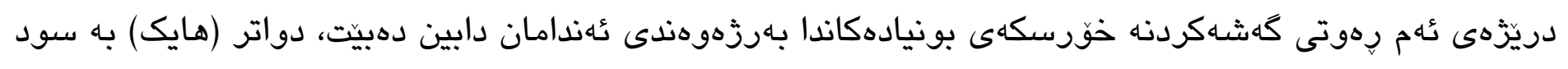

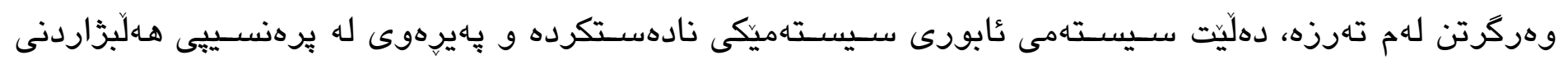

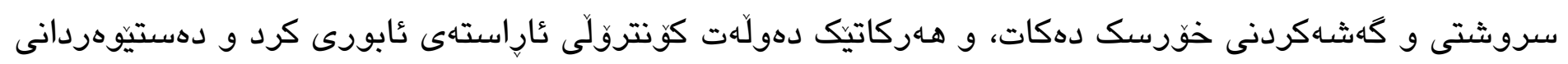




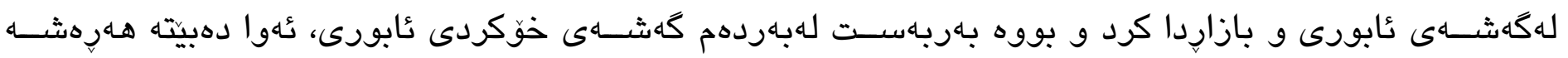

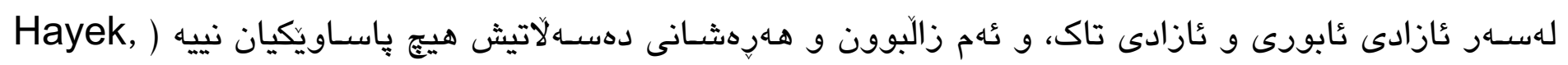

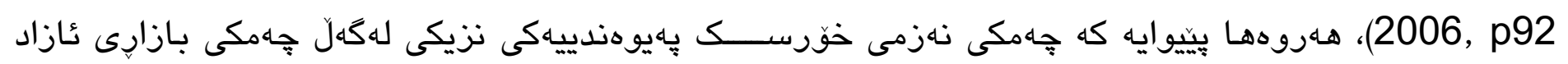

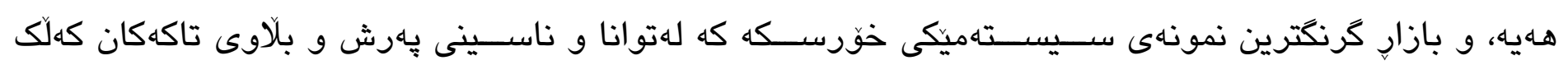
وهردهكريّت، هـروهها دهليّت كه سـيستهمى بازار دابينكهرى ئهو بابهتهيه كه سـهرجهامى زانست و مهاعريفهى ليّره

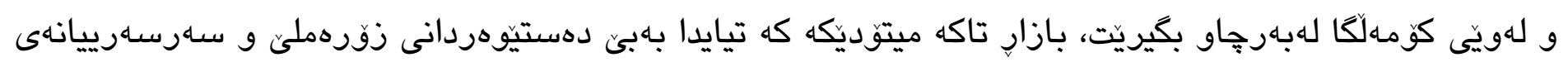

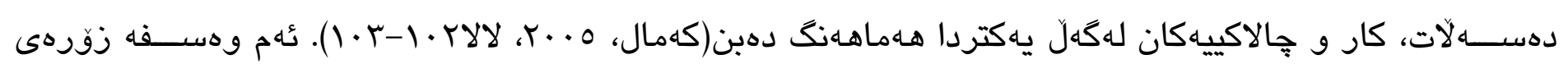
(هايك) بوّ بـازار و كردهى خوكردانى تُابورى وهك بنهماى عَازادى دهيكات، دهرخهرى ئهو بـاوهرهيهتى كه ئازادى

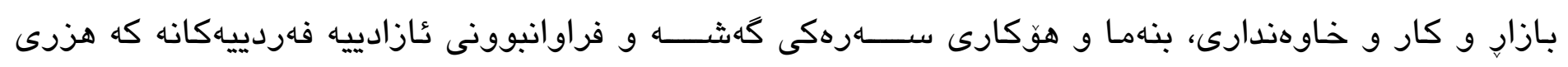

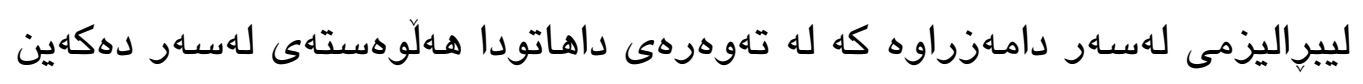

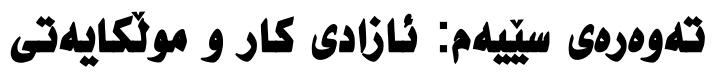

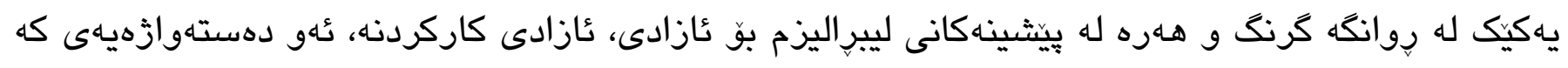

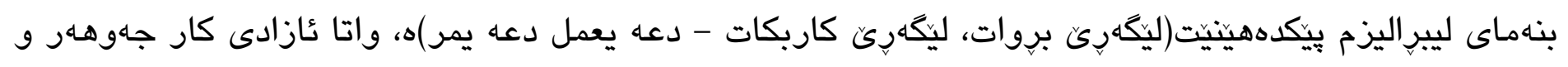

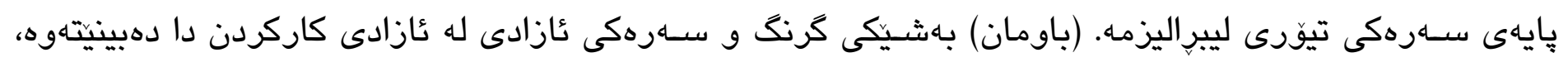

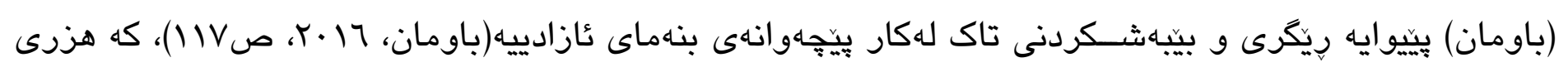
ليبزاليزمى للهسهر بيناكراوه.

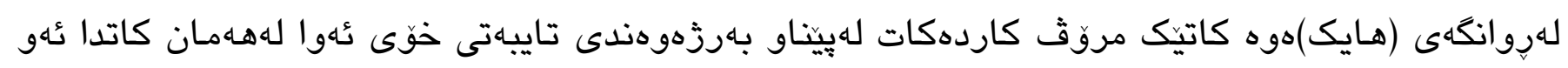

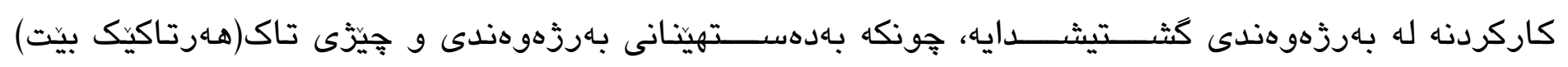

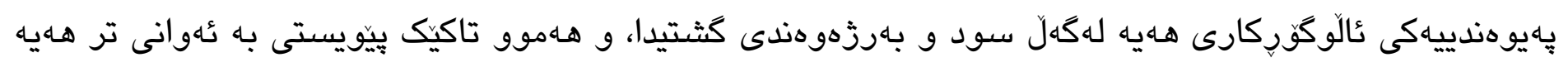

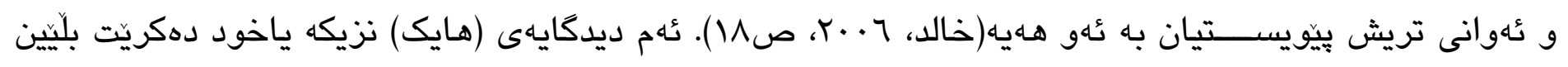

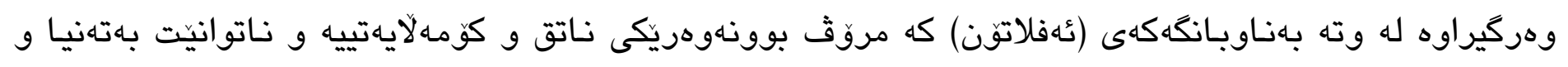

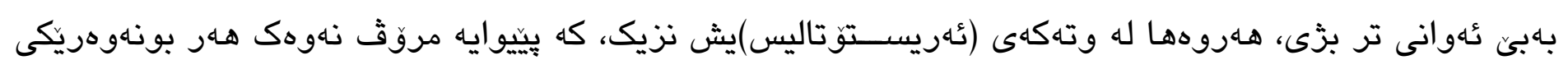

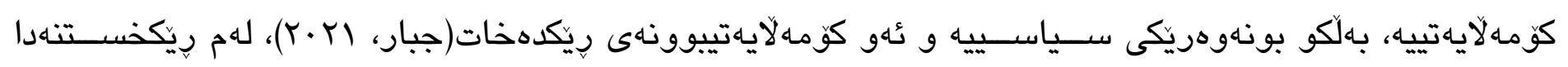

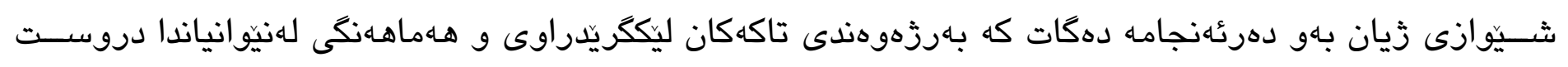

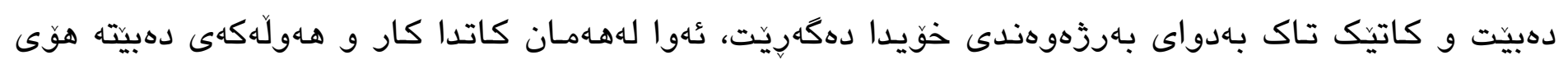

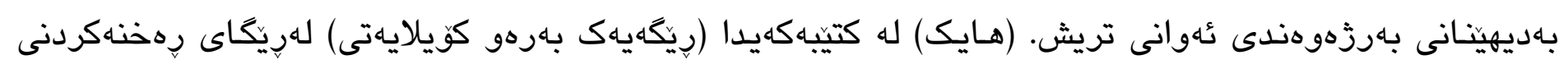

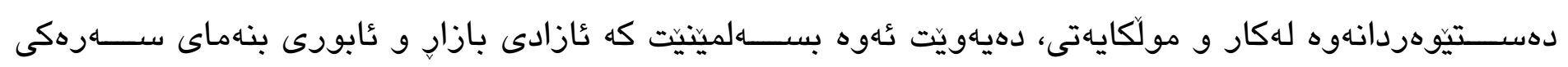


ئازادين، وهك دهلّيت بينيومانه كه له رابردوودا تهفسيراتهكان به كَزارشتى ئابورى نمونه بالآى سياسهتى يِيشوو

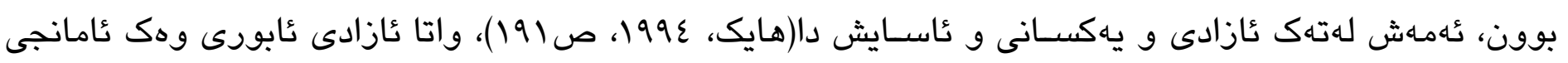

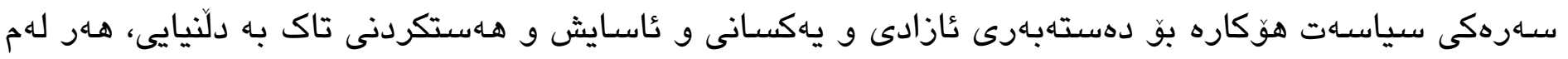

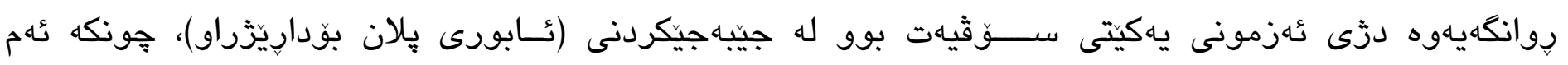

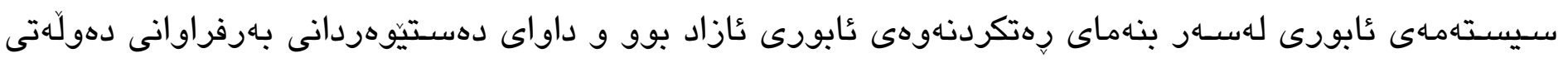

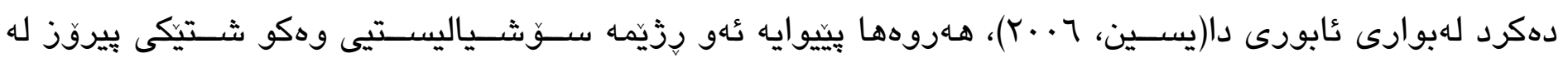

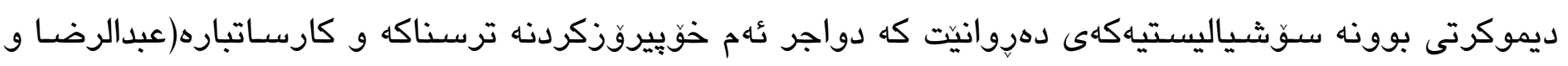

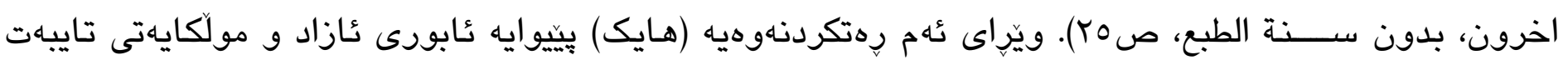

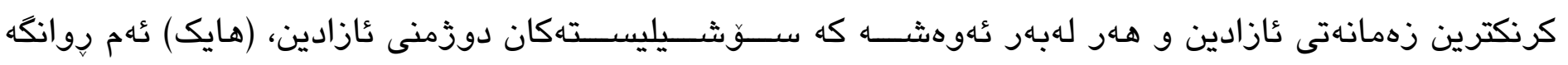

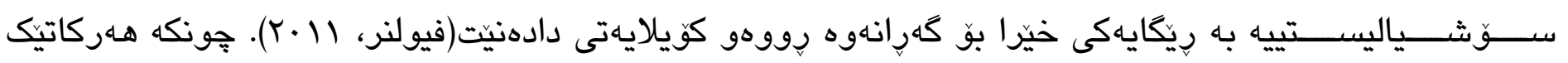

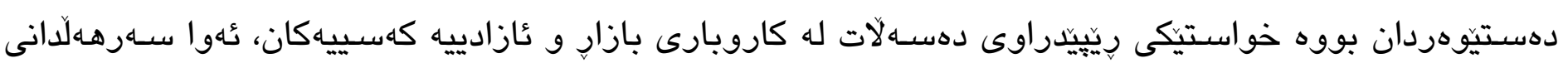

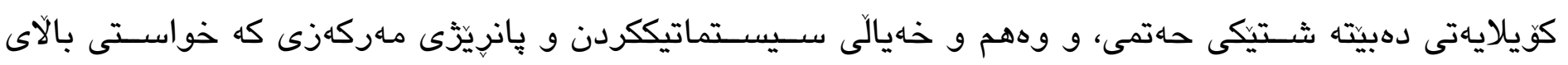

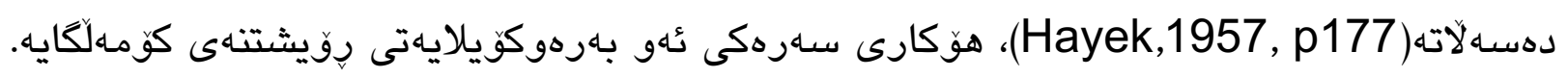

له هزرى (هايك) دا ئازادى مولكايهتى و ئابورى له دوو لايهنهوه شـايانى كرنكيييدانى زياتره، لايهنى يهكهم

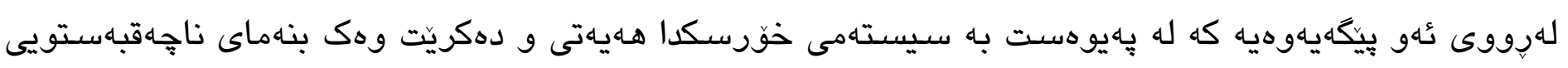

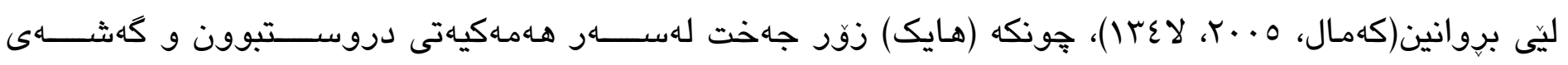

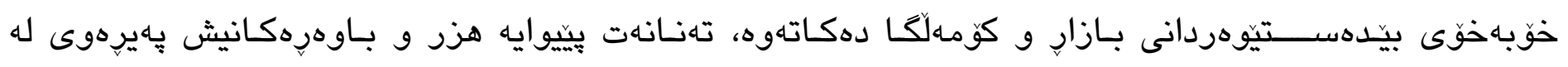

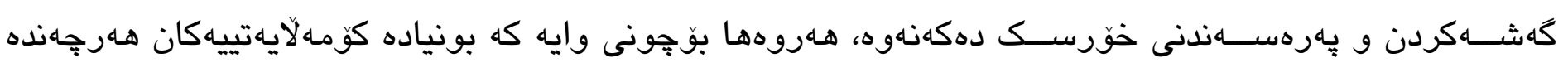

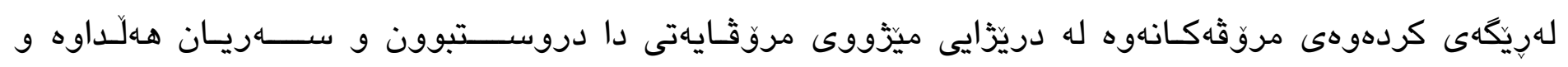

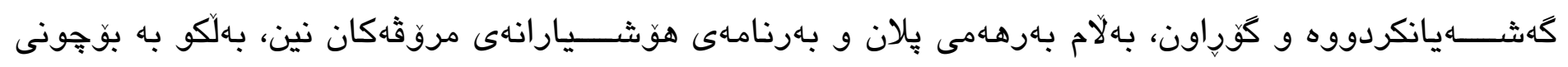

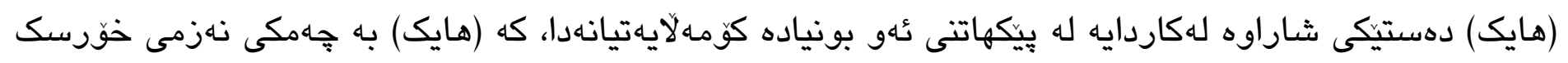

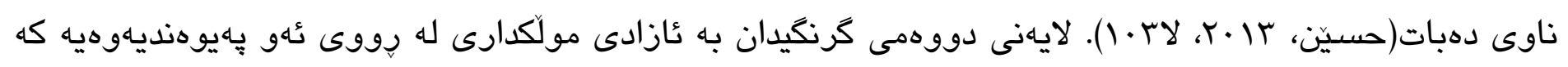

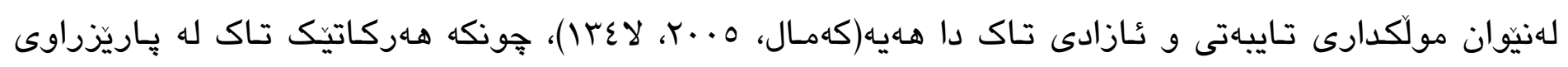

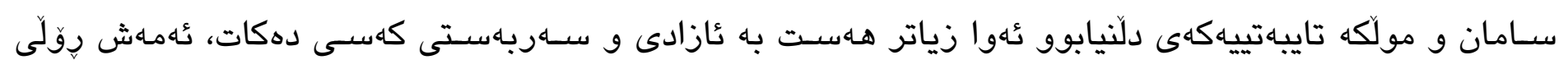

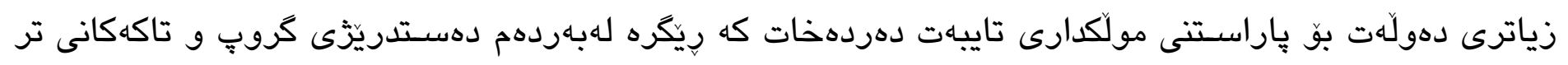

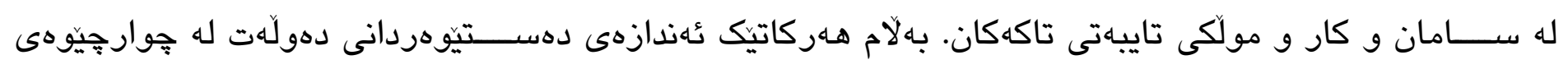

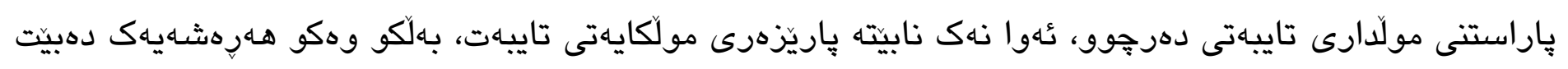

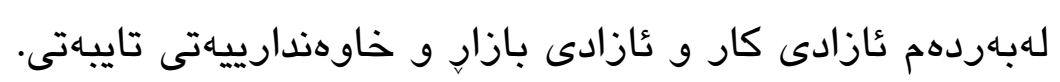


ئازادى تهنيا جهامكيكى رووت نييه، بهلكو برسيكّه فهلسهفى و هزرييه و پِهيوهسته به ماهيهت و بونيادى

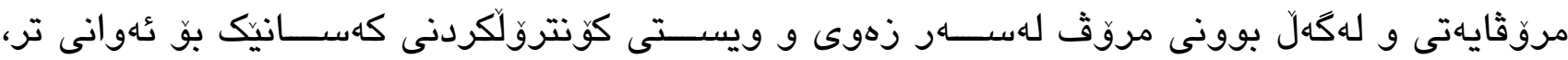
هاتقته بهرباس و مشتومرِ لهسـركردن. هزرى ليير الى له كَنكترين ثٔهو هزرانهيه كه دهربارهى ئازادى دواوه و تهنانهت بنهماى فهلسهاهى ليبراليزم ههار خودى ئازادييه.

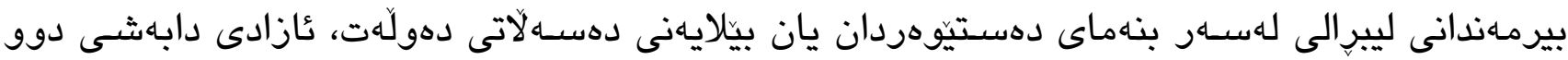

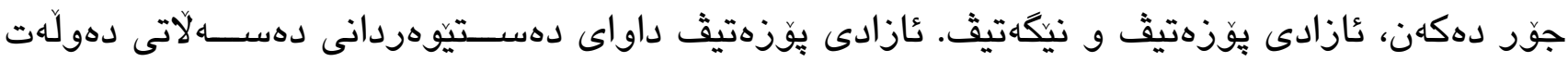

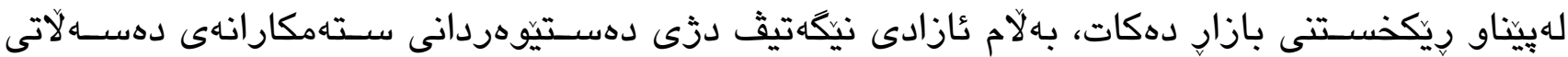
دهولَهته له بازار و ئابورى و عازادييهكانى تاك دا.

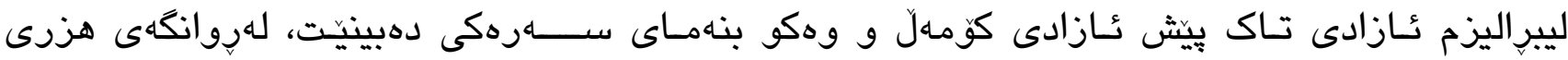

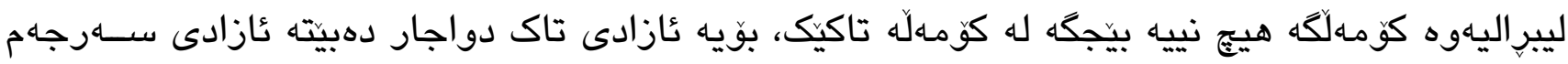

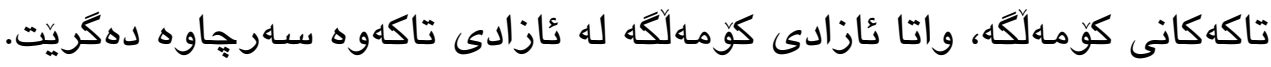

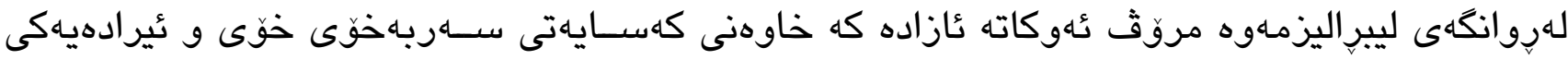

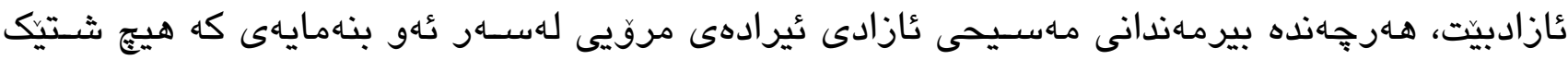
لهسهروى ئيرادهى خواوهنييه، رهتدهكهنهوه. ل

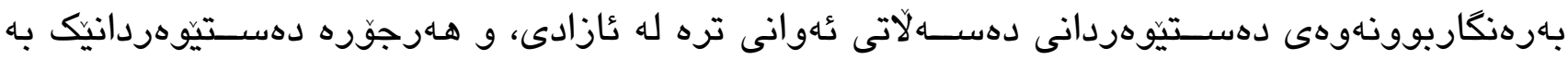

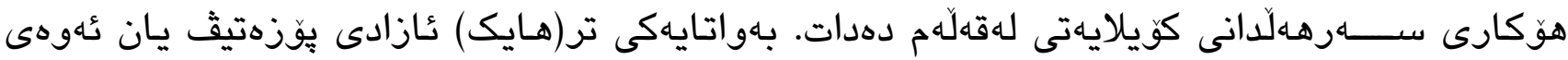

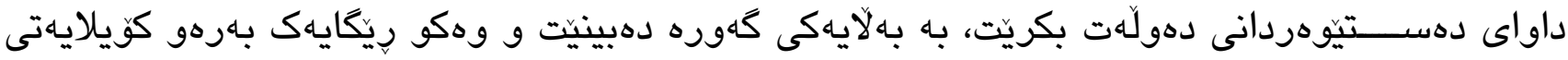

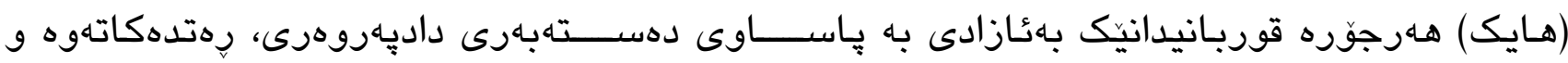

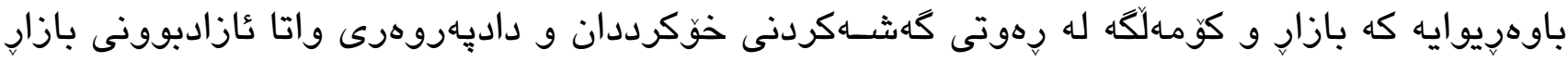

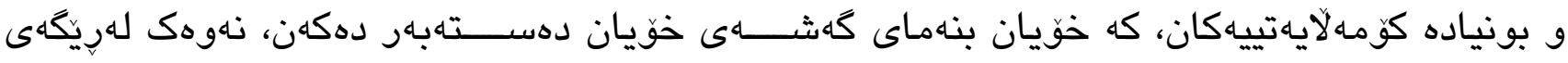

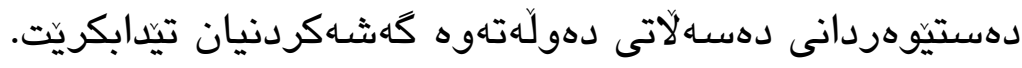

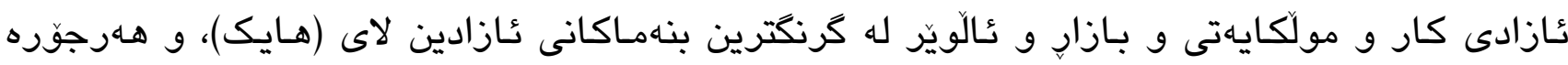
سنورداركردنيكى ئازادى بازار و ئابورى دواجار مانايهك بو بنهماكانى ترى ئازادى ناهيلّيّتهوه. 


\section{فلهرهلنَّوَك}

عايزيا بهرلين Sir Isaiah Berlin- السير أشـعيا برلين) فهيلهسوفى بهريتانى، ماموّستاى تيوّردى

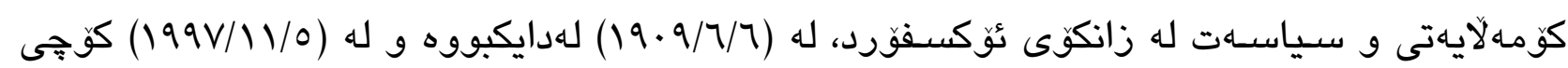
دوايى كردووه.

توماس هيلّ كرين (Thomas Hill Green- توماس هيل غرين، والمعروف باســــ تي إتش غرين)

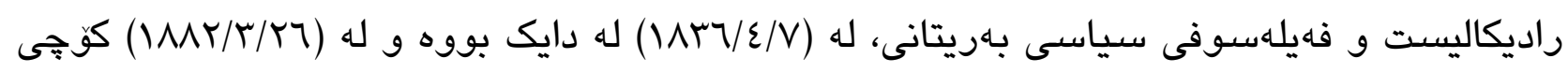
دوايى كردووه.

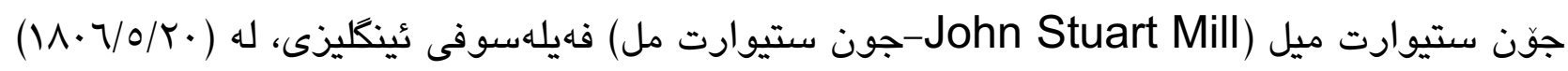

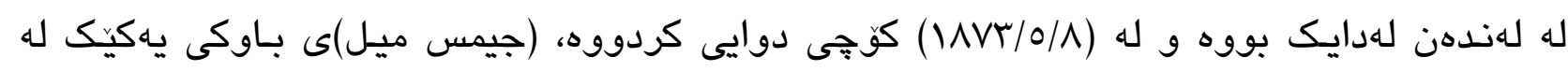

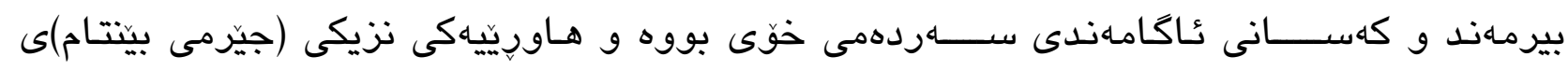

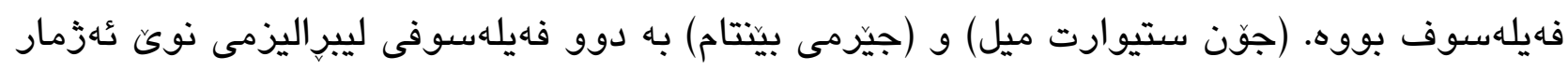

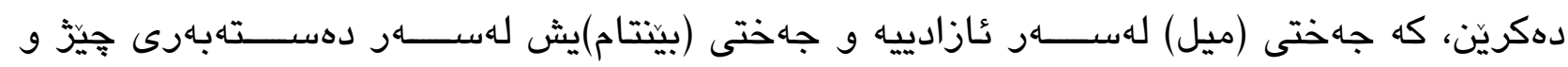
دووربوون له ئازاره.

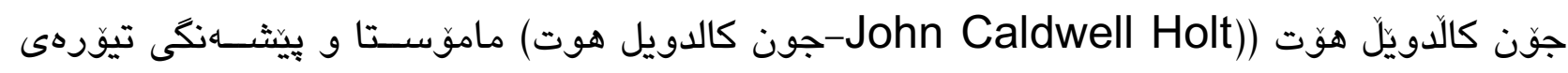

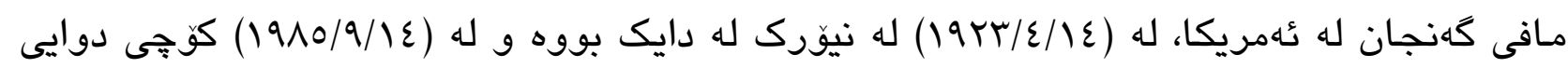
كردووه.

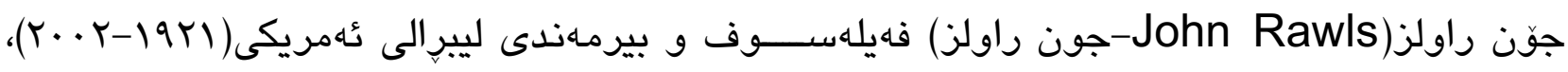

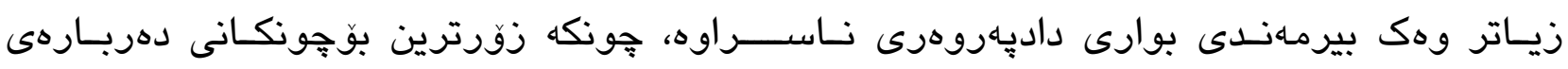

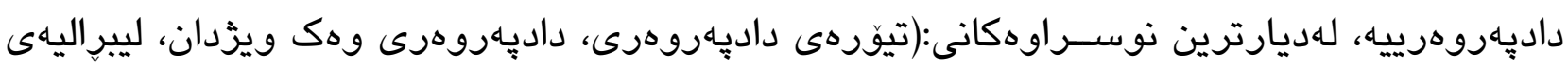
سياسى).

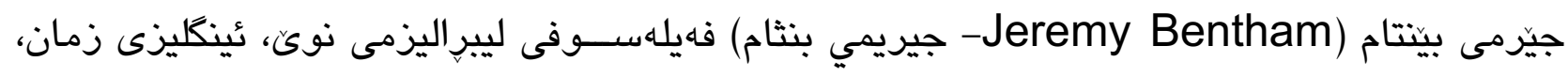

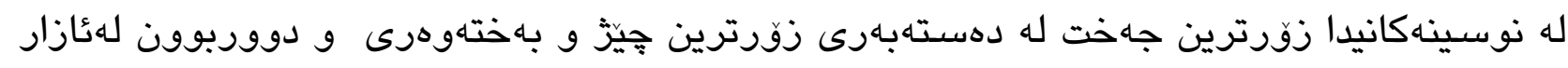

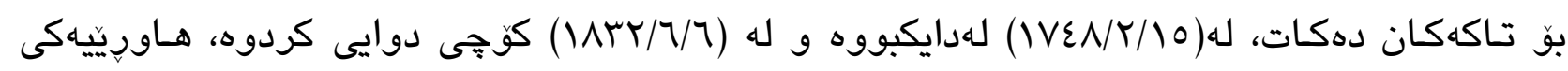

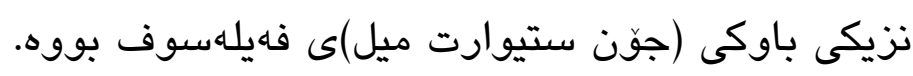

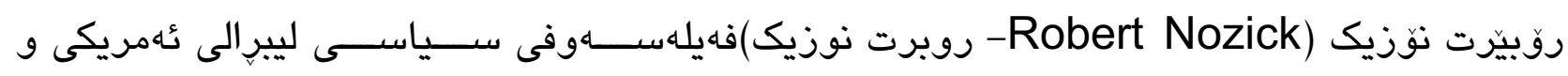

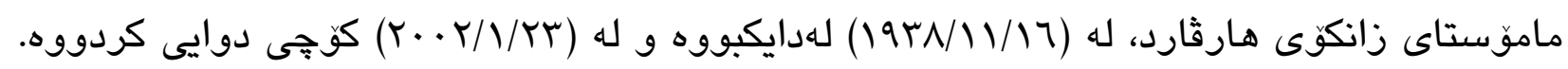




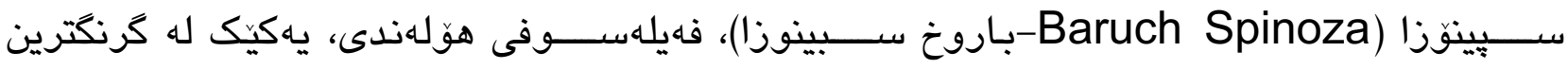

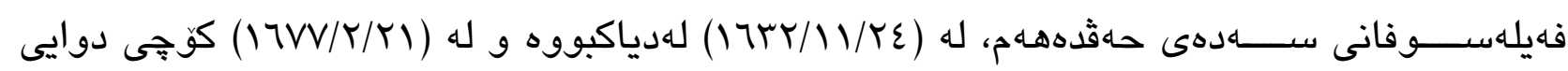
كردووه. فريدريك فوّن هايك Friedrich August von Hayek-فريدريخ اوغوســت فون هايك): تُابورى

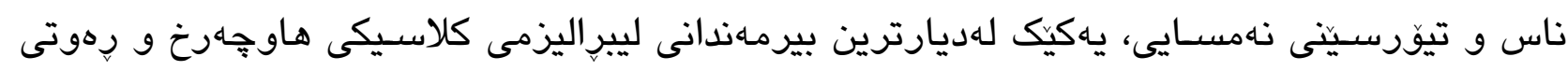

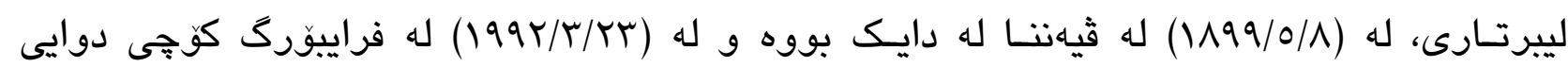
كردووه.

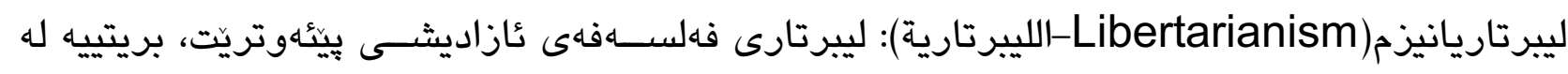

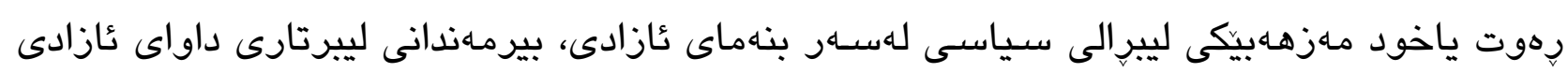

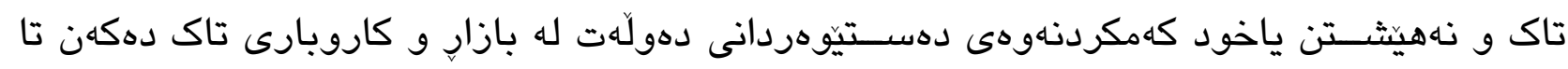

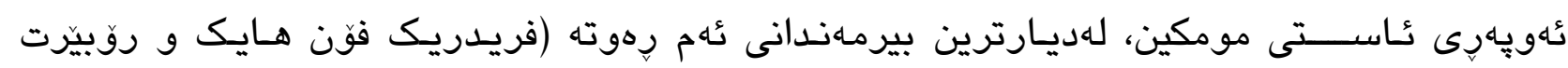
نوزيك)ن.

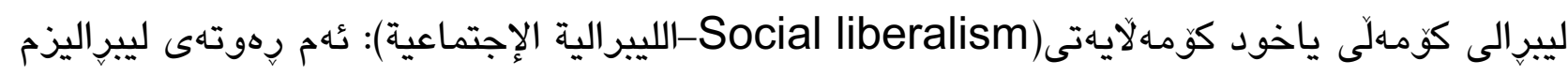

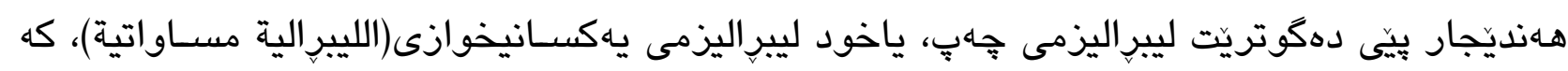

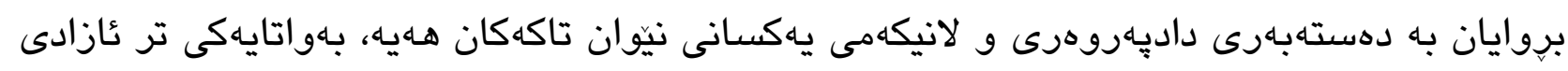

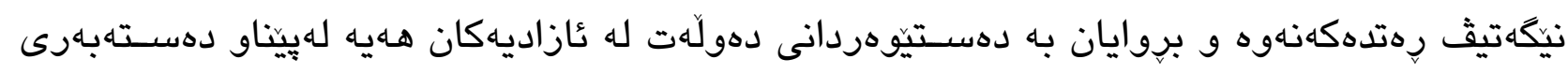

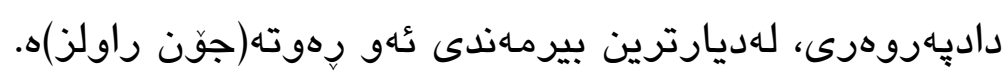

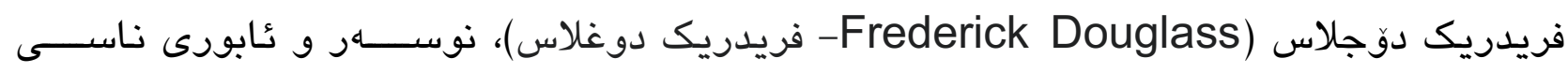

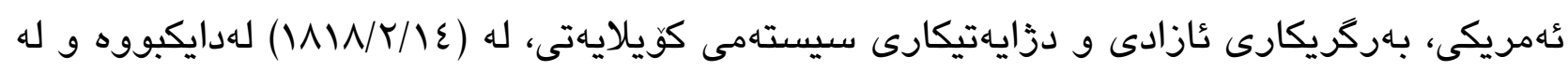
(1/90/r/r·)

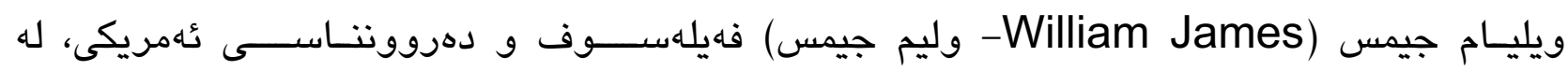

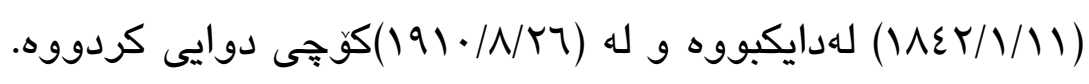




\title{
The Concept of Freedom in liberalism's Thought, for Instance: Friedrich .A. Von Hayek's Vision
}

\section{Jabar Ismael Ahmed}

Department of Political Science, College of Political Science, University of Sulaimani, Sulaimani, Kurdistan Region, Iraq.

E-mail: jabar.ahmed84@gmail.com

\begin{abstract}
:
Liberalism thus views the concept of freedom as a fundamental element of its intellectual foundation and without access to and defense of freedom, there is no meaning for the existence and survival of liberals .Due to the wide range of views of liberalism and the differences of opinion of liberal thinkers and different trends, attitudes and views on different freedoms, for example some of the thinkers believe in the interference of the state power in personal freedoms with the goal of creating social justice and economic justice and so on..., such as the thinkers of the Social liberal trend in the thought of liberalism, But some other thinkers believe in the protection of individual freedoms from interfering of the power of the state, and reject any form of interference in freedom, such as thinkers of the Libertarians trend in the thought of liberalism, including (Friedrich A. von Hayek).
\end{abstract}

These two views of liberalism are expressed in terms of freedom, as: positive freedom (when the state intervenes in freedoms), and negative freedom (that freedom is protected from the interference of state power). (Hayek) rejects positive freedom and believes that any interference in the freedom, economy, and property of individuals, commodities, and markets, leads to the deterioration of the security and stability of individuals on one hand, and the creation of an oppressive, tyrannical and dictatorial power or regime on the other hand. This condition becomes the cause and means of the departure of individuals and the coexistence of the living system to slavery.

Keywords: Freedom, Hayek, Liberalism, Libertarianism. 


\section{سلوجهاومكان}

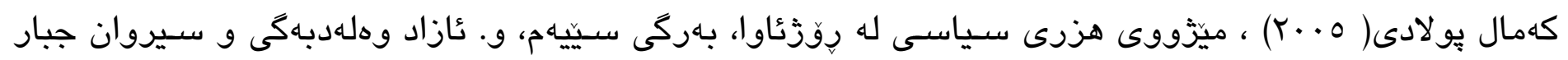
زهندى، دهزكاى جاب و بلأوكردنهوهى موكريان، هـوليّر.

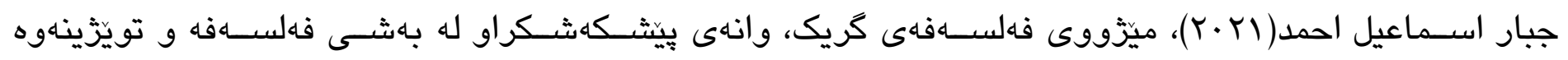
كولتورييهكان - كوليزى زانسته مروقايهتييهكان- زانكوى سليمانى، قؤناغى يهكه، سيميستهرى يهكهم.

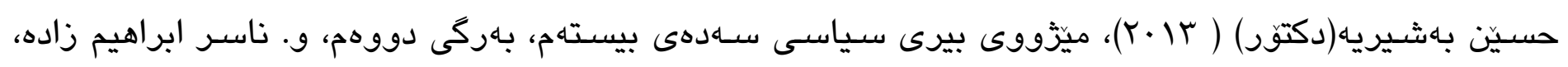
خانهى موكريانى بق جاب و بلاوكردنهوه، هدوليّر.

موسا ابراهيم(·(r)، فكرى سياسى خوّرئاوا له ماكياثيلييهوه تا ماركس، و. شوان احمد، عَ، سليمانى.

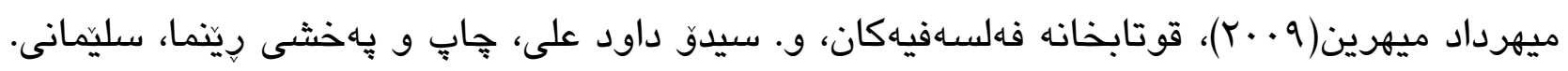

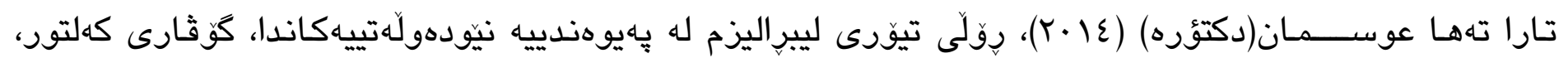

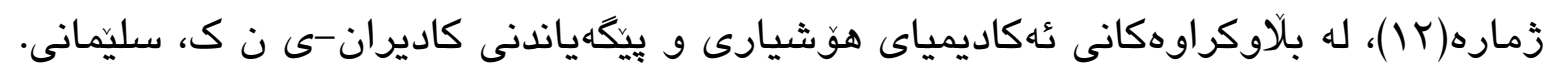

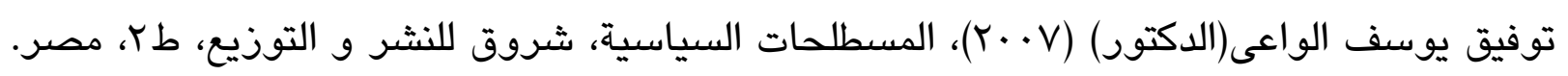
هونر احمد كريم(N|(Y)، إشـكالية تدخل الدولة فى فكر الليبرالى المعاصـر، رسـالة ماجستير غير منشـورة، جامعة

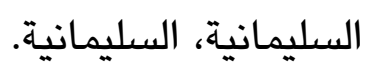

بول. ف. بولر(19v1)، الحرية و القدر فى فكر الامريكى، ت. اسماعيل كثميرى، مكتبة الانجلو المصرية، مصر. جوت هولت(19VY)، الحرية و ماوراءها، ت. نظمى لوقا، دار المعارف، القاهرة. جون ديوى(1900)، الحرية و الثقافة، ت. امين مرسى قنديل، مطبعة التحزين، مصر. خالد محمد خالد(7 -. ا)، أزمة الحرية فى عالمنا، دار المقط، القاهرة. 
ديفيد هارفى(r (Y)، الوجيز فى تاريخ النيوليبرالية، ت. وليد شـحاتة، وزارة الثقافة السـورية-الهيئة العامة السـورية للكتاب، دمشق. زكريا ابراهيم(الدكتور) (ب7 (197)، مشكيلة الحرية، مكتبة مصير، طז، القاهرة. زيغمونت باومان(7 ( / (Y)، الحرية، ت. فريالحسن خليفة، مكتبة فكر جديد، بدون مكان الطبع. ستانلى موريسون(Y) (Y)، الحرية، الهيئة العامة القصور الثقافة، القاهرة. ستيفن دى تانسى(rا ·r)، علم السياسية الاسس، ت. رشا جمال، الشبكة العربية للأبحاث و النشر، ط؟، بيروت.

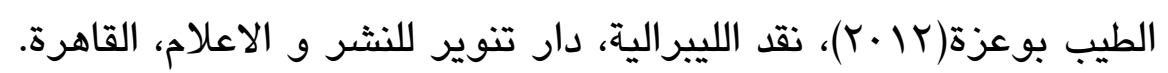
عبدالرحيم بن صمايل السـمى(الدكتور) (9 ·. (Y)، حقيقة الليبرالية و موقف الاسـلام منها، مركز التاصيل للدراسـات و البحوث، المملكة العربية السعودية-جدة. عبدالله عروى(1999)، مفهوم الحرية، المركز الثقافى العربى، طه، بيروت.

عبدالرضــــا حســين طعان(الدكتور)، عـامر حســن فياض(الدكتور)، على عباس مراد(الدكتور)، حســــام بـاقر غرباوى(الدكتور) (بدون سنة الطبع)، مدخل الى فكر السياسى الغربى الحديث و المعاصر، جزء الثانى، بغداد. ف.ا.هايك(ع 199)، الطريق الى العبودية، ت.محمد مصطفى غنيم، دار الشروق، القاهرة. كولن فارلى(^^ • r)، مقدمة فى النظرية الســياسـية المعاصــرة، ت. محمد زاهي بثــير المغيربي(الدكتور) و نجيب المحجوب الحصادى(الدكتور)، دار الكتب الوطنية، بنغازى-لييا.

مراد ديانى(ع (Y)، حرية-مساوات-اندماج الاجتماعى، المركز العربى للابحاث و دراسة السياسات، بيروت، ع •r. عبدالامير و أخرون(9 ( †)، فلسفة الحرية، مركز دراسات الوحدة العربية، لبنان. 
ويل كيملشكا(·( (؟)، مدخل الى الفلسفة السياسية المعاصرة، ت. منير الكثو، المركز الوطنى للترجمة، تونس.

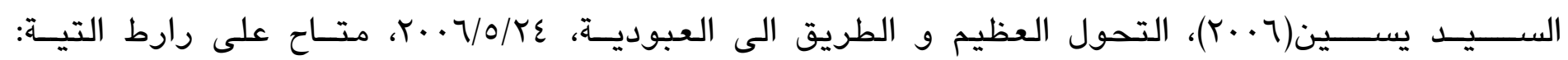
. http://www.maaber.org/issue_may08/books_and_readings $2 . h t m$

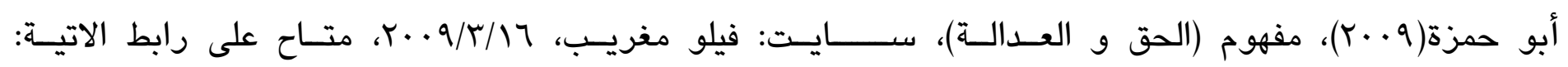
. http://www.philomaghreb.com/bb/viewtopic.php?f=42\&t=1256

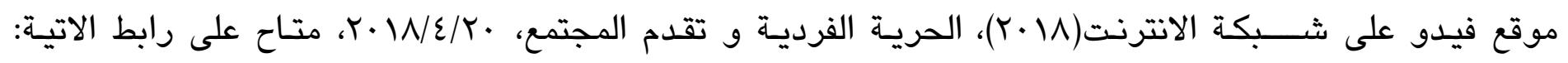
http://www.feedo.net/QualityOfLife/QualityOfLifeBasics/IndividualFreedomAndSocietyProgre . $\underline{\text { ss.htm }}$

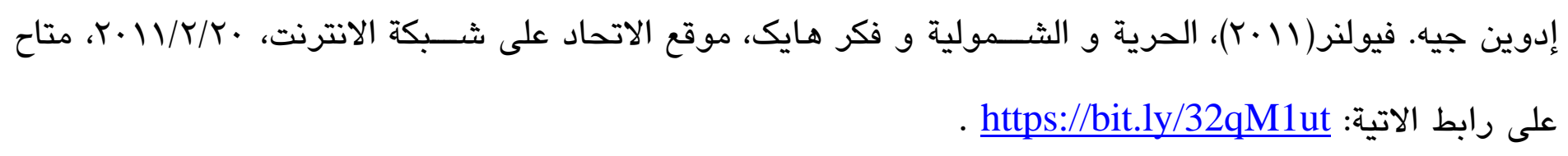
F.A.Hayek(1958), In dividualism and economic order, third impression, the university of Chicago press, Chicago.

F.A.Hayek(1981), Law legislation and liberty, V3, the university of Chicago press, Chicago.

F.A.Hayek(1990), New studies in philosophy, politics, economics and the history of ideas, second publish, Routledge, London and New york.

F.A.Hayek(2006), The road to serfdom, 5th publish, Routledge, London and New york.

Jeremy Shearmur(1996), Hayek and after-Hayekian liberalism as a research programme, Routledge, London and New York.

Mill, john Stuart,(2001), on liberty, batoche books, Ontario-canada. 